
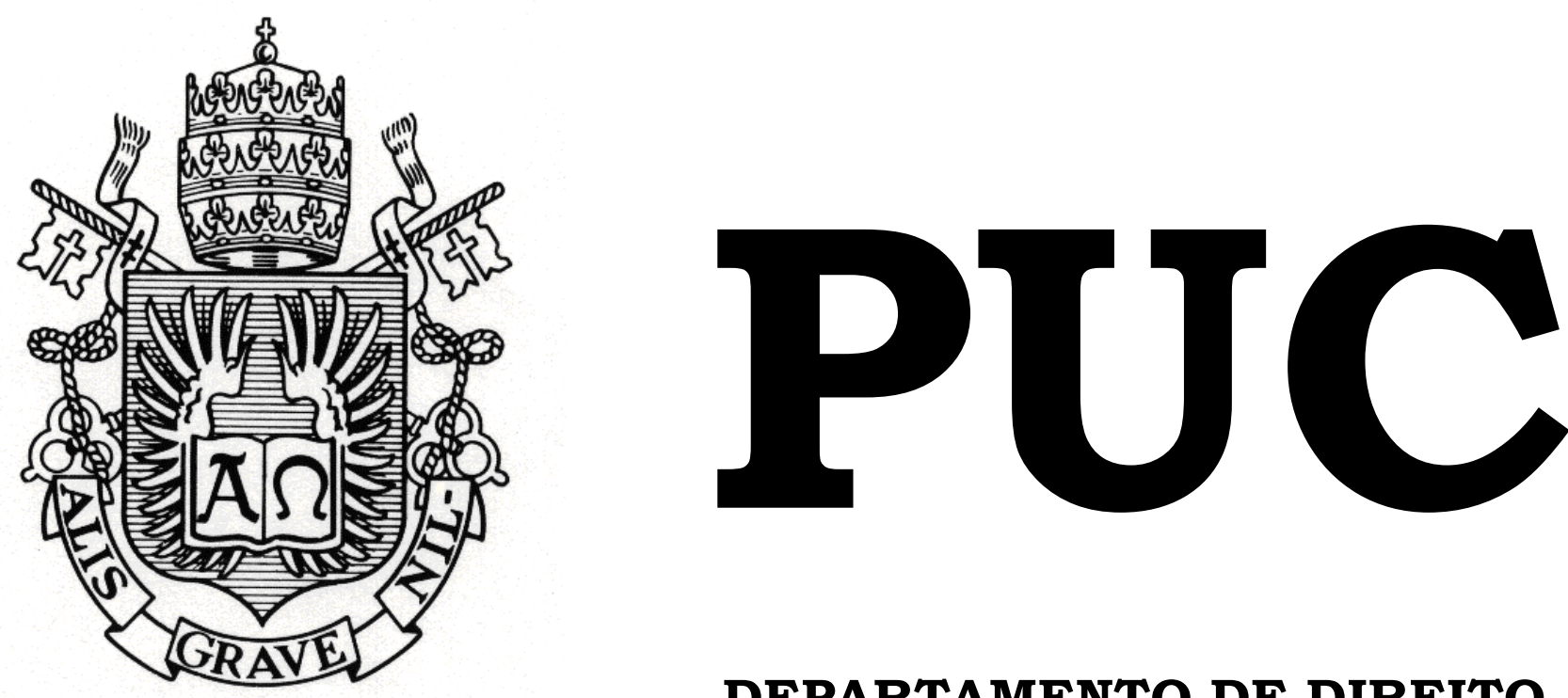

DEPARTAMENTO DE DIREITO

\title{
O PAPEL DO SENADO FEDERAL NO CONTROLE DE CONSTITUCIONALIDADE JUDICIAL
}

$$
\text { por }
$$

HUGO SEABRA FAGUNDES SOARES DE MOURA

ORIENTADORA: Regina Coeli Lisbôa Soares

2017.1

PONTIFÍCIA UNIVERSIDADE CATÓLICA DO RIO DE JANEIRO RUA MARQUÊS DE SÃO VICENTE, 225 - CEP 22453-900 RIO DE JANEIRO - BRASIL 


\title{
O PAPEL DO SENADO FEDERAL NO CONTROLE DE CONSTITUCIONALIDADE JUDICIAL
}

\author{
por
}

\section{HUGO SEABRA FAGUNDES SOARES DE MOURA}

Monografia

apresentada

ao

Departamento de Direito da Pontifícia Universidade Católica do Rio de Janeiro (PUC-Rio) para a obtenção do Título de Bacharel em Direito.

Orientadora: Regina Coeli Lisbôa Soares 


\section{Agradecimentos}

$\mathrm{O}$ meu primeiro agradecimento tem de ser feito à minha família. Foram muitas as situações em que pensei em desistir; mas, graças aos exemplos que tenho "em casa", persisti nessa jornada.

Gostaria de agradecer também à Clara, que desde o primeiro período esteve ao meu lado e me apoiou durante toda a faculdade. Nada teria sido possível sem o seu apoio.

Não posso deixar de agradecer às minhas amigas da faculdade - Julia Potsch e Caroline Carneiro. Sem vocês, a faculdade não teria tido graça.

Também tenho de agradecer aos meus amigos do estágio na Procuradoria-Geral do Estado. Minhas tardes foram muito divertidas com vocês.

Por fim, agradeço à minha orientadora, Regina Soares, por toda a paciência e disponibilidade durante a elaboração desse trabalho. 


\section{Resumo}

O presente trabalho tem como objetivo principal analisar a função exercida pelo Senado Federal no controle difuso de constitucionalidade. Essa modalidade de controle foi introduzida pela Constituição de 1891 e o constituinte de 1934 concebeu o mecanismo de atuação do Senado para conferir efeitos gerais à decisão do Supremo Tribunal Federal que produzia efeitos entre as partes. Essa técnica, entretanto, não foi imune a críticas, as quais se intensificaram com o desenvolvimento do controle abstrato pela Constituição de 1988, que manteve a competência do Senado para atuar no controle concreto. Nesse sentido, analisa-se a teoria da mutação constitucional do art. 52, X elaborada por Gilmar Mendes e desenvolvida durante o julgamento da Reclamação 4.335/AC. Portanto, o presente trabalho busca analisar a função do Senado, atualmente, no controle de constitucionalidade difuso, destacando-se a possível mutação constitucional do dispositivo.

\section{Palavras-chave:}

Poder Judiciário, Supremo Tribunal Federal, Súmula Vinculante, Controle de Constitucionalidade Difuso, Senado Federal, Artigo 52, X, Reclamação 4.335/AC, Mutação Constitucional, Limites. 


\section{Sumário}

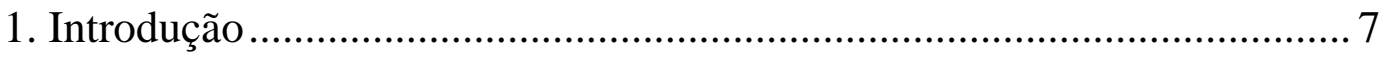

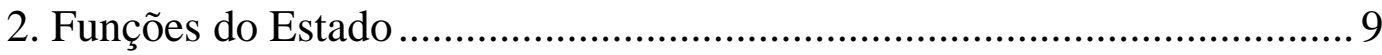

2.1. Histórico da tripartição dos Poderes e sua aplicação no Brasil ...........9

2.2. O papel do Judiciário na organização do Poder no Brasil.................. 13

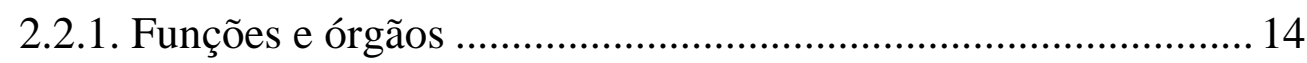

2.2.2. O Supremo Tribunal Federal .................................................... 15

2.2.2.1. Competências ..................................................................... 18

2.2.2.1.1. Recurso Extraordinário.................................................. 19

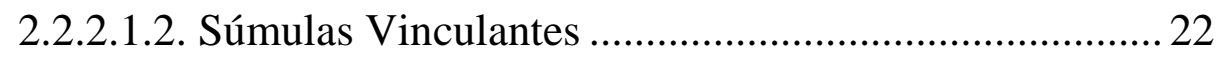

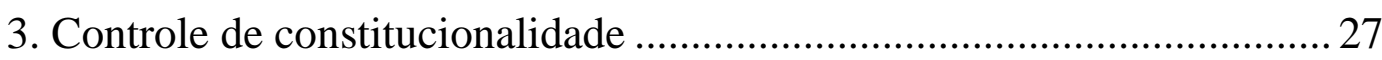

3.1. O fenômeno da inconstitucionalidade ............................................. 27

3.1.1. Os planos da existência, validade e eficácia................................ 27

3.1.2. Nulidade da norma inconstitucional ............................................ 29

3.2. Leading case: Marbury v. Madison................................................... 30

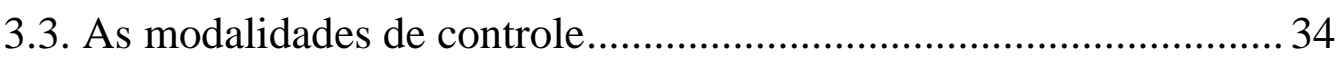

3.4. Sistema brasileiro de controle de constitucionalidade ....................... 39

3.4.1. Desenvolvimento histórico do sistema brasileiro........................ 40

3.4.1.1. Constituição do Império do Brasil (1824) ............................ 40

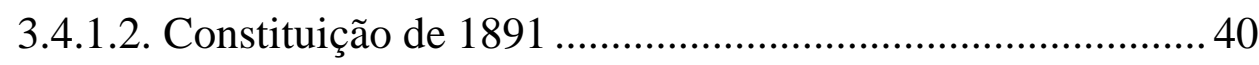

3.4.1.3. Constituição de 1934 ............................................................. 42

3.4.1.4. Constituição de 1937 ........................................................... 43

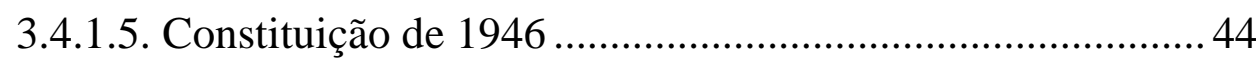

3.4.1.6. Constituição de 1967 e a Emenda Constitucional n. 1 de

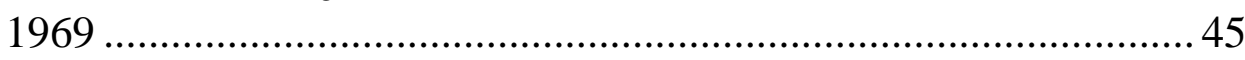

3.4.2. O sistema judicial de controle na Constituição de 1988 ............ 46

3.5. Controle por via incidental ou concreto …………………………..... 48

3.5.1. Controle difuso no Supremo..................................................... 52 
3.5.2. Efeitos da decisão do Supremo e o artigo 52, X da Constituição .55

4. A Reclamação 4.335/AC: uma nova manifestação do Supremo sobre o

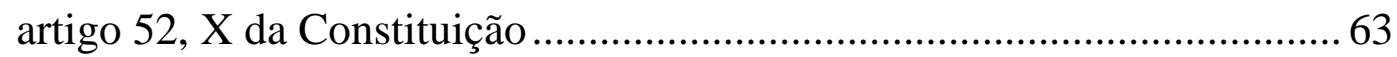

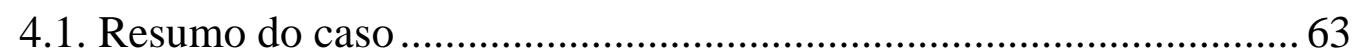

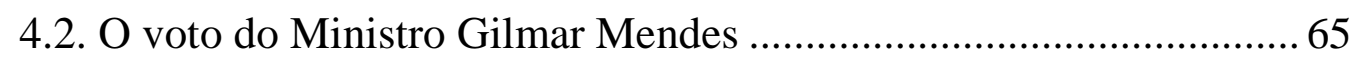

4.3. O voto do Ministro Eros Grau ............................................................. 70

4.4. O fenômeno da mutação constitucional ............................................. 71

4.5. A mutação (in) constitucional do artigo 52, X da Constituição ........ 74

4.6. A decisão do Supremo Tribunal Federal na Reclamação 4.335/AC 78

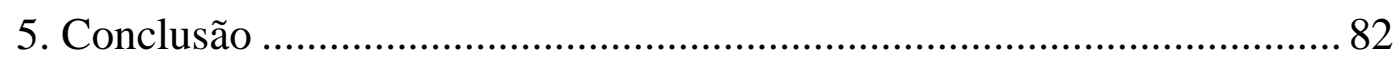

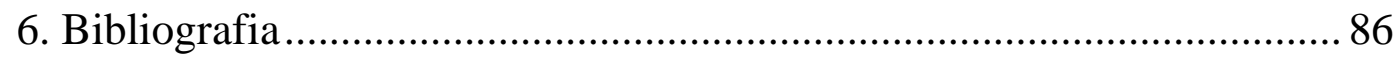




\section{Abreviações}

ADC - Ação Direta de Constitucionalidade

ADI - Ação Direta de Inconstitucionalidade

ADIO - Ação Direta de Inconstitucionalidade por Omissão

AO - Ação Originária

Art. - Artigo

CPC - Código de Processo Civil

CRFB - Constituição da República Federativa do Brasil

EC - Emenda Constitucional

HC - Habeas Corpus

MS - Mandado de Segurança

Rcl - Reclamação

RE - Recurso Extraordinário

RISTF - Regimento Interno do Supremo Tribunal Federal

SE - Sentença Estrangeira

STF - Supremo Tribunal Federal 


\section{Introdução}

A modernidade presume mudanças e, nos últimos anos, elas se intensificaram. São diversas as metamorfoses experimentadas pelos mais diversos meios, como social, político, econômico. A ciência do Direito não está imune a transformações; e nem poderia, uma vez que o Direito deve guardar relação com a sociedade para que não seja apenas palavras em papel, sem nenhuma aplicação prática.

Um exemplo dessas grandes mudanças pode ser observado no Direito Constitucional, mais especificamente no controle de constitucionalidade. Esse mecanismo passou por diversas alterações durante a história constitucional brasileira. Todo esse caminho culminou na Constituição de 1988 (acrescida por algumas Emendas e regulamentada por algumas Leis), que trouxe um sistema de controle de constitucionalidade complexo.

Fala-se, atualmente, em sistema complexo porque o Direito brasileiro foi além de conjugar os dois sistemas de controle: abstratoconcentrado e concreto-difuso. Hoje, é possível perceber uma conexão entre esses sistemas que, antes, eram vistos como isolados.

Dentro deste cenário de aproximação dos sistemas de controle de constitucionalidade, faz-se necessário revisitar instrumento singular adotado pelo legislador brasileiro, qual seja, a atuação do Senado Federal no controle de constitucionalidade difuso (art. 52, X, da Constituição Federal).

Esse instrumento, que foi elaborado pelo legislador constituinte de 1934, visava conferir, por meio da atuação do Senado Federal, eficácia geral às decisões do Supremo Tribunal Federal sobre a inconstitucionalidade de uma norma.

Assim, em um cenário de aproximação dos sistemas de controle de constitucionalidade, cabe o questionamento se a atuação do Senado ainda se justifica. E mais, cabe o questionamento se esse dispositivo constitucional 
sofreu um processo de alteração informal (mutação constitucional) ou se conserva o mesmo sentido que possuía em sua origem.

Para analisar esse tema, o presente trabalho apresentará, em primeiro lugar, o princípio da tripartição dos Poderes e o papel que o Poder Judiciário exerce no constitucionalismo brasileiro. Esse primeiro tópico se justifica na medida em que o controle de constitucionalidade é capaz de suscitar questões acerca do princípio da tripartição dos Poderes; um eventual reconhecimento, por parte do Poder Judiciário, da mutação constitucional de um dispositivo que trata de uma competência do Senado é capaz de suscitar diversos questionamentos sobre o princípio.

Em seguida, o presente trabalho faz uma análise do sistema de controle de constitucionalidade adotado pelo Direito brasileiro. Esse sistema, como já foi dito, deixou de prever de maneira isolada os modelos abstrato-concentrado e concreto-difuso, passando a conceber um sistema em que esses modelos estão intimamente conectados.

Por fim, o presente trabalho analisa a possível mutação constitucional do dispositivo que prevê a atuação do Senado Federal no controle difuso (art. 52, X, CRFB). 


\section{Funções do Estado}

\subsection{Histórico da tripartição dos Poderes e sua aplicação no Brasil}

A teoria da tripartição dos Poderes está incorporada ao constitucionalismo moderno, e visa estabelecer uma estrutura estatal que impossibilite a concentração dos poderes em uma única pessoa ou órgão, evitando a tirania.

A ideia de tripartição poderia levar os mais desavisados ao entendimento de que o Poder pode ser fracionado. Entretanto, essa ideia é inverídica, uma vez que o Poder é produto da vida em sociedade, pois quando há a adesão a um grupo social, automaticamente, há a permissão para que esse mesmo grupo passe a moldar as atividades de seus integrantes. Percebe-se, portanto, que o Poder é algo inerente ao grupo, posto que o indivíduo que integra o grupo permite que esse tenha a capacidade de nortear suas ações.

É exatamente esse raciocínio aplicado ao Estado, dado que se trata do grupo social de mais alta escala e detentor do Poder soberano. Nesse sentido, cabe expor lição elucidativa de José Afonso da Silva:

\footnotetext{
"O Estado, como grupo social máximo e total, tem também o seu poder, que é o poder político ou poder estatal. A sociedade estatal, chamada também de sociedade civil, compreende uma multiplicidade de grupos sociais diferenciados e indivíduos, aos quais o poder político tem que coordenar e impor regras e limites em função dos fins globais que ao Estado cumpre realizar"1.
}

Seguindo o pensamento de José Afonso, percebe-se que o Poder Político é superior a todos os outros poderes oriundos de grupos sociais, cabendo àquele reger esses. Das particularidades do Poder Político, decorrem suas três características fundamentais: unidade, indivisibilidade e indelegabilidade. E, em razão dessas qualidades do Poder Estatal, não se

\footnotetext{
${ }^{1}$ SILVA, José Afonso da. Curso de Direito Constitucional Positivo. 36a ed. São Paulo: Malheiros, 2012. p. 109.
} 
deve entender que há uma divisão do Poder ao se tratar das atividades executiva, legislativa e judiciária.

A ideia de separar os poderes do Estado em diferentes órgãos é, atualmente, bem internalizada pelas sociedades que vivem em uma democracia. Contudo, o sistema não teve início nos moldes atuais. O que vemos hoje é resultado de um processo que modificou a teoria durante vários séculos.

O precedente mais remoto da teoria da separação de poderes vem do pensamento de Aristóteles. Na obra "A Política", o filósofo grego já distinguia as três funções do Estado e considerava perigoso concentrá-las em uma mesma pessoa ou órgão. Segundo o pensamento aristotélico, o Estado teria três tarefas: a primeira seria a de nomear magistrados, além de deliberar sobre as leis e deliberar sobre as relações externas, estabelecendo alianças, declarando guerra e celebrando a paz; a segunda seria a de decidir, que era atribuída aos magistrados; e em terceiro lugar, estaria a função jurisdicional ${ }^{2}$.

Outras tantas referências foram feitas por outros pensadores de renome no curso da história, como Marsílio de Pádua que, no ano de 1324, em sua obra "Defensor Pacis", estabeleceu diferenças entre o Poder Legislativo e o Poder Executivo. Outra referência de destaque remonta à obra mais conhecida de Nicolau Maquiavel, "O Príncipe", a qual faz alusão de existir na França do século XVI três Poderes distintos: Executivo, Legislativo e Judiciário ${ }^{3}$.

A ideia de repartição das funções estatais também foi objeto de estudo de John Locke. Entretanto, segundo o pensador inglês, o Estado possuiria quatro funções fundamentais, as quais deveriam ser exercidas por dois órgãos, o Parlamento e o Rei ${ }^{4}$.

A teoria da repartição das funções estatais se cristalizou no século XVIII com o Barão de Montesquieu. Isso ocorreu muito em função da ideia

\footnotetext{
${ }^{2}$ Cf. Aristóteles, A Política. Livro III, Cap. XI.

${ }^{3}$ Cf. Maquiavel, Nicolau. O Príncipe. XIX

${ }^{4}$ Cf. Locke, John. Segundo Tratado sobre o Governo. XII, XIII e XIV.
} 
de equilíbrio estar muito presente à época, permeando os mais diversos campos, desde a política, com a ideia de divisão dos poderes para constituir uma estabilidade, como faziam, por exemplo, Charles Montesquieu e David Hume, até a física com Isaac Newton, que tratava do equilíbrio das forças gravitacionais e centrífugas no sistema solar.

Finalmente, então, com Montesquieu, a teoria da separação de poderes toma a forma que é adotada pelas mais diferentes constituições ao longo do tempo. No modelo do filósofo francês, já há a concepção da existência de três poderes, os quais deveriam ser exercidos por órgãos distintos, caso contrário, a liberdade dos cidadãos estaria ameaçada:

"Tudo estaria perdido se o mesmo homem, ou o mesmo corpo dos principais, ou dos nobres, ou do povo exercesse os três poderes: o de fazer as leis, o de executar resoluções públicas e o de julgar os crimes ou as querelas entre os particulares"

Observa-se, então, que, para Montesquieu, os Poderes Executivo, Legislativo e Judiciário, deveriam ser exercidos por órgãos distintos, de maneira a criar uma sociedade em equilíbrio, na qual a liberdade dos cidadãos seria respeitada.

O exercício do poder político incumbe ao governo, o qual é formado pelo conjunto de órgãos por meio do qual a vontade do Estado é manifestada. Assim, apesar de comumente se usar o termo "governo" para se referir a quem exerce a função executiva, o governo é na realidade quem exerce as funções do poder político.

A divisão dos poderes, a qual consiste, segundo José Afonso da Silva em "confiar cada uma das funções governamentais (legislativa, executiva e jurisdicional) a órgãos diferentes, que tomam o nome das respectivas funções, menos o Judiciário"6, já era objeto de estudos, como exposto

\footnotetext{
5 Montesquieu, O Espírito das Leis, Livro XI, Cap. VI. p.168. Disponível em <http://www.escolapresidentevargas.com.br/base/www/escolapresidentevargas.com.br/media/attac hments/331/331/539ef6ac8641be2d6b331d74d2ecf96bc0ab67efa1c59_montesquieu.-o-espiritodas-leis.pdf> . Acesso em 3. mar. 2017.

${ }^{6}$ Silva, José Afonso. Op. cit., p. 110.
} 
anteriormente, desde a época de Aristóteles e se consolidou no cenário político com a Constituição dos Estados Unidos e a Revolução Francesa.

Atualmente, o princípio já não possui a rigidez do passado, pois o Estado é chamado a atuar de maneira diferente do que fazia à época em que a ideia de separação dos poderes foi concebida. Dessa forma, modernamente, o relacionamento entre os poderes é visto de outra maneira, falando-se em independência orgânica e harmonia entre os poderes.

Desse modo, a antiga distribuição das funções do Estado como modelo estanque estaria superada. É exatamente por essa lógica que o entendimento do professor Dalmo Dallari está orientado:

\begin{abstract}
"Na verdade as próprias exigências de efetiva garantia de liberdade para todos e de atuação democrática do Estado requerem deste maior dinamismo e a presença constante na vida social, o que é incompatível com a tradicional separação dos poderes. É necessário que se reconheça que o dogma da rígida separação formal está superado, reorganizando-se completamente o Estado, de modo a conciliar a necessidade de eficiência com os princípios democráticos"7.
\end{abstract}

Foi exatamente seguindo a ideia de independência e harmonia entre os poderes que a Constituição de 1988 foi elaborada, como deixa claro o artigo $2^{\circ}$. O princípio da separação dos poderes é tão fundamental na ordem constitucional brasileira que é colocado pelo legislador originário como cláusula pétrea (artigo $60, \S 4^{\circ}, \mathrm{III}$ ), impossibilitando que qualquer emenda que possa tender a sua abolição seja objeto de deliberação.

Em relação à separação de poderes como cláusula pétrea, vale lembrar o pronunciamento do Eminente Ministro Celso de Mello, no julgamento do MS 23.452/RJ:

"O sistema constitucional brasileiro, ao consagrar o princípio da limitação de poderes, teve por objetivo instituir modelo destinado a impedir a formação de instâncias hegemônicas de poder no âmbito do Estado, em ordem à neutralizar, no plano político-jurídico, a possibilidade de dominação institucional de qualquer dos Poderes da República sobre os demais órgãos de soberania nacional"8.

\footnotetext{
${ }^{7}$ DALLARI, Dalmo de Abreu. Elementos de teoria geral do Estado. 32a ed. São Paulo: Saraiva, 2013. p 220.

${ }^{8}$ STF, MS n. 23.452/RJ, Rel. Min. Celso de Mello, Brasília, 12 mai. 2000.
} 
Os órgãos do governo, que manifestam a vontade do Estado, são independentes, entretanto isso não implica dizer que inexistam interferências entre eles, pelo contrário, os órgãos devem interferir uns nos outros de maneira a criar um sistema de freios e contrapesos, evitando qualquer concentração, a qual criaria um risco para as liberdades dos cidadãos.

Exemplos desse sistema de freios e contrapesos são facilmente observados no texto constitucional. Um exemplo marcante é o processo legislativo, o qual é matéria tratada do artigo 59 ao artigo 69. Segundo o texto constitucional, cabe ao Poder Legislativo a edição de normas gerais e impessoais, tendo o Poder Executivo grande participação, podendo propor uma lei ou uma emenda à Constituição, além de deter o poder de sanção ou veto. Entretanto, essa capacidade que o Executivo possui de propor normas é compensada pela capacidade do Legislativo de promover alterações no texto normativo ou de rejeitar a proposta do Executivo. Ademais, o Executivo pode vetar o que lhe é enviado pelo Congresso. Para balancear esse poder do Executivo, o Legislativo pode, por meio da maioria absoluta de seus membros, derrubar o veto presidencial, cabendo ao Presidente do Senado promulgar a lei se assim o Presidente não atuar. Em regra, os Tribunais não podem interferir no processo legislativo, todavia são autorizados a declarar a inconstitucionalidade de normas, deixando de aplica-las aos casos concretos.

\subsection{O papel do Judiciário na organização do Poder no Brasil}

O Poder Judiciário é o que se encontra, de certa maneira, mais distante dos demais, pois os Poderes Executivo e Legislativo apresentam-se entrelaçados em suas atividades. Nesse sentido, Gilmar Mendes explica o elemento que em seu entendimento singulariza o Poder Judiciário:

"Destaca-se que, diferentemente, do Legislativo e do Executivo, que se encontram em relação de certo entrelaçamento, o Poder Judiciário, ou a 
Jurisdição, é aquele que de forma mais inequívoca se singulariza com referência aos demais Poderes. Konrad Hesse observa que não é o fato de o Judiciário aplicar o Direito que o distingue, uma vez que se cuida de afazer que, de forma mais ou menos intensa, é levado a efeito pelos demais órgãos estatais, especialmente pela Administração. Todavia, o que caracterizaria a atividade jurisdicional é a prolação de decisão autônoma, de forma autorizada e, por isso, vinculante, em casos de direitos contestados ou lesados".

A Constituição de 1988, por meio de seu Título IV, estabeleceu a organização dos poderes no Estado brasileiro. Por meio desse segmento, o constituinte tratou dos poderes Executivo, Legislativo e Judiciário nos Capítulos I, II e III, respectivamente; tratou ainda, por meio do Capítulo IV desse Título, das funções essenciais à Justiça.

\subsubsection{Funções e órgãos}

A Constituição logo ao iniciar o Capítulo que trata do Judiciário já elenca os órgãos pertencentes a esse Poder:

“Art. 92. São órgãos do Poder Judiciário:

I - o Supremo Tribunal Federal;

I-A o Conselho Nacional de Justiça;

II - o Superior Tribunal de Justiça;

II-A - o Tribunal Superior do Trabalho;

III - os Tribunais Regionais Federais e Juízes Federais;

IV - os Tribunais e Juízes do Trabalho;

V - os Tribunais e Juízes Eleitorais;

VI - os Tribunais e Juízes Militares;

VII - os Tribunais e Juízes dos Estados e do Distrito Federal e Territórios".

A Constituição, ainda, conferiu autonomia institucional a esse Poder da República, configurando significante inovação na história constitucional brasileira. Também ficou estabelecida a autonomia administrativa e financeira do Poder Judiciário, além de se assegurar a autonomia funcional dos magistrados.

A ordem judiciária foi estabelecida dessa maneira para que os princípios constitucionais de livre acesso ao Judiciário, da proteção judicial

\footnotetext{
${ }^{9}$ MENDES, Gilmar Ferreira; BRANCO Paulo Gustavo Gonet. Curso de direito constitucional. $8^{\mathrm{a}}$ ed. São Paulo: Saraiva, 2013. p. 935.
} 


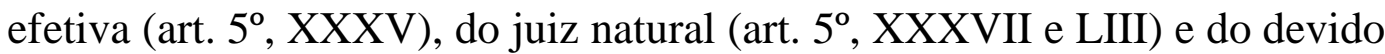
processo legal (art. $\left.5^{\circ}, \mathrm{LV}\right)$ fossem efetivamente aplicados.

A independência dos órgãos do Poder Judiciário dos demais Poderes é condição sine qua non para que ele exerça uma de suas funções, qual seja, controlar a atuação estatal, seja ela por conduta da Administração, seja por conduta do Poder Legislativo, esse último configurando o controle de constitucionalidade.

Além das autonomias institucional, administrativa e financeira, a Constituição, com o intuito de garantir um Poder Judiciário o mais isento possível e com capacidade para realizar suas funções de maneira adequada, instituiu garantias e limitações aos membros desse Poder. Segundo o artigo 95 da Constituição, são garantias dos membros do Poder Judiciário: vitaliciedade, inamovibilidade e irredutibilidade de vencimentos.

Já em relação às limitações, conforme o parágrafo único do dispositivo supracitado, é estabelecido que é vedado aos juízes: exercer, ainda que em disponibilidade, outro cargo ou função, salvo uma de magistério; receber, a qualquer título ou pretexto, custas ou participação em processo; dedicar-se à atividade político-partidária; receber, a qualquer título ou pretexto, auxílios ou contribuições de pessoas físicas, entidades públicas ou privadas, ressalvadas as exceções previstas em lei; exercer a advocacia no juízo ou tribunal do qual se afastou, antes de decorridos três anos do afastamento do cargo por aposentadoria ou exoneração.

\subsubsection{O Supremo Tribunal Federal}

O Supremo Tribunal Federal é o órgão de cúpula do Poder Judiciário e é também o órgão mais antigo da ordem judiciária brasileira, com sua origem remontando ao Supremo Tribunal de Justiça, criado em 1828 e instalado no ano seguinte e que possuía dezessete Ministros.

A Constituição de 1891 ratificou a instituição do Supremo Tribunal Federal, que havia sido feita pelo Governo Provisório por meio do Decreto 
n. 848 , de 11/10/1890. Nos moldes dessa Constituição, o Supremo era composto por quinze membros que deveriam ser nomeados pelo Presidente e aprovados pelo Senado Federal. A Constituição Republica, influenciada pela Constituição Americana, foi responsável por promover uma nova concepção do Poder Judiciário. Dessa forma, o Supremo Tribunal Federal passou a ter a atribuição de proteger a Constituição e a ordem federativa, sendo competente para aferir, mediante a interposição de um recurso especial, a constitucionalidade da aplicação do Direito. O Supremo também era competente para atuar nos casos de conflito entre União e Estadosmembros ou entre os últimos.

A Revolução de 1930 trouxe alterações ao Supremo Tribunal Federal. Por meio do Decreto n. 19.656, de 03/02/1931, o Governo Provisório, o qual acumulava as funções legislativas e executivas, reduziu o número de Ministros para onze e os dividiu em duas turmas. O Supremo Tribunal Federal, com o advento da Constituição de 1934, que instituiu novamente uma ordem democrática, passou a ter a denominação de Corte Suprema, a qual permanecia sendo composta por onze Ministros nos moldes estabelecidos pelo governo de Getúlio Vargas no início da Revolução. As competências básicas do Supremo, que haviam sido definidas na primeira Constituição republicana brasileira, foram mantidas pela Constituição de 1934.

A ordem democrática que havia sido instalada com a Constituição de 1934 foi encerrada pela adoção da Constituição de 1937, que foi outorgada por Getúlio Vargas e ficou conhecida como "Constituição Polaca" por ter sido baseada na Constituição polonesa do governo do General Pilsudski. As competências do Supremo Tribunal Federal não foram significativamente alteradas, todavia a atuação da Corte deveria ser pautada na Constituição de 1937, a qual era totalmente totalitária. Uma mudança ocorrida na vigência da Constituição Polaca em relação ao STF que merece destaque é a reinvindicação feita pelo Presidente da República, por meio do Decreto-Lei 
n. 2.770, de 11/11/1940, de nomear o Presidente e o Vice-Presidente da Corte.

O governo ditatorial instalado em 1937 chegou ao fim com a promulgação da Constituição de 1946, que possuía índole democrática. Essa Constituição previa onze Ministros no Supremo Tribunal Federal. Ao Supremo foi assegurada competência para julgar recursos extraordinários nos casos de violação da Constituição ou de lei federal, habeas corpus e mandados de segurança, entre outras.

A Constituição de 1946 encontrou seu fim com a chegada dos militares ao poder, quando editaram o Ato Institucional n. 1, em 09/04/1964. O Supremo Tribunal Federal experimentou diversas mudanças com o golpe, passando a atuar numa espécie de resistência jurídica ao Movimento Militar, tentando proteger liberdades dos cidadãos. Nesse sentido, importante lembrar que os Ministros Victor Nunes, Hermes Lima e Evandro Lins e Silva foram aposentados de maneira compulsória durante o Regime Militar. O Ato Institucional n. 2, de 27/10/1965, promoveu diversas mudanças no ordenamento jurídico nacional, estabelecendo, por exemplo, a eleição indireta para presidente. Foi com esse ato que o Supremo Tribunal Federal teve sua composição alterada, passando a ser constituído por dezesseis Ministros. Ademais, as garantias da magistratura, as quais são fundamentais para se estabelecer uma ordem democrática, foram suspensas. Com o advento da Constituição de 1967, a situação do Supremo não sofreu notável transformação. No governo ditatorial dos militares, a Corte voltou a ser composta por onze Ministros (Ato Institucional n. 6). Importante destacar que as Constituições de 1967 e 1969 outorgavam força de lei ao Regimento Interno do Supremo. A partir de 1969, o papel político do STF foi bastante reduzido. Vale ressaltar que apenas com a revogação do Ato Institucional n. 5, em 1978, as garantias aos magistrados foram restabelecidas.

Atualmente, o Supremo Tribunal Federal é composto por onze Ministros. A escolha destes Ministros é feita pelo Presidente da República e 
deve ser aprovada pelo Senado. O artigo 101 da Constituição estabelece os critérios para a indicação:

“Art. 101. O Supremo Tribunal Federal compõe-se de onze Ministros, escolhidos dentre cidadãos com mais de trinta e cinco e menos de sessenta e cinco anos de idade, de notável saber jurídico e reputação ilibada.

Parágrafo único. Os Ministros do Supremo Tribunal Federal serão nomeados pelo Presidente da República, depois de aprovada a escolha pela maioria absoluta do Senado Federal".

A composição do Tribunal é feita conforme estabelecido no Regimento Interno, como explica Gilmar Ferreira Mendes:

\begin{abstract}
"Com exceção do Presidente do Tribunal, cada Ministro integra, formalmente uma Turma. As Turmas têm competências idênticas e os processos não são distribuídos, originariamente, a uma ou a outra Turma, mas a determinado Ministro Relator, que, por sua vez, pertence à Primeira ou à Segunda Turma (RISTF, art. 66), O Presidente de cada Turma é escolhido pelo critério de antiguidade (RISTF, art. $4^{\circ}, \S^{\circ}$ ).

Para as matérias mais relevantes, a exemplo da decisão sobre constitucionalidade ou inconstitucionalidade, o Tribunal Pleno somente poderá deliberar se presentes oito dos onze Ministros. Para decisão sobre a constitucionalidade das leis (declaração de constitucionalidade ou de inconstitucionalidade), exige-se sempre maioria de seus votos (RISTF, art. $173 \mathrm{c} / \mathrm{c}$ art. 174)"10.
\end{abstract}

O Presidente da Corte é escolhido mediante voto dos Ministros para um mandato de dois anos (RISTF, art. 12), sendo a reeleição vedada. Por costume, são eleitos para os cargos de Presidente e Vice-Presidente do Supremo os dois Ministros mais antigos que ainda não exerceram esses cargos.

\title{
2.2.1. Competências
}

O artigo 102 da Constituição de 1988, por meio de seu inciso I, estabelece quais são as hipóteses que cabem ao Supremo Tribunal Federal julgar de maneira originária, isto é, as situações contempladas nesse

\footnotetext{
${ }^{10}$ Ibid. p. 954.
} 
dispositivo devem ser iniciadas diretamente no órgão de cúpula do Poder Judiciário. Além da competência para julgar originariamente, a Constituição também estabeleceu hipóteses em que o Supremo é acionado via recursos, podendo ser por via de recurso ordinário (art. 102, II) ou recurso extraordinário (art. 102, III).

Além dessas competências explícitas na Constituição, já se encontra consolidado na jurisprudência do Supremo a possibilidade de a Corte exercer uma série de competências que estariam implícitas no texto constitucional. Para demonstrar esse posicionamento do Supremo Tribunal Federal, Gilmar Ferreira Mendes cita alguns julgamentos:

“a) Mandado de Segurança contra ato de Comissão Parlamentar de Inquérito.

b) Habeas Corpus contra a Interpol, em face do recebimento de mandado de prisão expedido por magistrado estrangeiro, tendo em vista a competência do STF para processar e julgar, originariamente, extradição solicitada por Estado estrangeiro (CF, art. 102, I, g).

c) Mandado de segurança contra atos que tenham relação com pedido de extradição (CF, art. 102, I, g).

d) A competência do STF para julgar mandado de segurança contra atos da Mesa da Câmara dos Deputados (art. 102, I, d, $2^{\mathrm{a}}$ parte) alcança os atos individuais praticados por parlamentar que profere decisão em nome desta.

e) Habeas corpus contra qualquer decisão do STJ, desde que configurado o constrangimento ilegal" "11.

As situações em que o Supremo atua em razão de competência implícita no texto constitucional não configuram casos de simples ampliação das competências determinadas pelo legislador; na realidade, no caso da atuação do STF em razão de competência implícita, o órgão é chamado a atuar em razão de uma interpretação compreensiva do texto constitucional.

\subsection{Recurso Extraordinário}

Como visto previamente, uma das competências do Supremo Tribunal Federal explícitas no texto constitucional é a de processar e julgar

\footnotetext{
${ }^{11}$ Ibid. p. 960.
} 
Recurso Extraordinário interposto contra decisão judicial proferida em última ou única instância (art. 102, III). Tal recurso é o instrumento processual cabível para se reformar decisão que atentar contra a Constituição. O recurso extraordinário é cabível, segundo a Constituição, quando uma decisão de última ou única instância: contrariar dispositivo da Constituição, declarar a inconstitucionalidade tratado ou lei federal, julgar válida lei ou ato de governo local contestado em face da Constituição, julgar válida lei local contestada em face de lei federal.

Observa-se, pelo exposto, que o recurso extraordinário possui pressupostos muito específicos para ser admitido pelo Supremo. Não basta que se trate de umas das hipóteses contempladas nas alíneas do inciso III do artigo 102 da Constituição, é necessário também que a decisão de que se quer recorrer seja proferida em única ou última instância.

Apesar dos casos deveras específicos de cabimento do recurso extraordinário, o STF vive uma crise numérica desses recursos. Referida crise não foi instaurada com a Constituição de 1988, ela já existia na ordem constitucional anterior à democratização. Entretanto, a crise numérica foi agravada pela nova constituição. Gilmar Ferreira Mendes propõe explicações para a intensificação da crise numérica dos recursos extraordinários:

\footnotetext{
"É verdade que a massificação das demandas nas relações homogêneas é um fator decisivo para essa crise. As discussões que se encetaram em determinado período sobre planos econômicos, sistema financeiro de habitação, Fundo de Garantia do Tempo de Serviço - FGTS, índices de reajuste do Instituto Nacional do Seguro Social - INSS, podem explicar com certa plausibilidade a multiplicação de demandas, especialmente em um modelo que trata cada controvérsia judicial instaurada como um processo singular" $" 12$.
}

Com o intuito de atenuar a crise numérica dos recursos extraordinários, foram elaboradas algumas defesas, tanto no âmbito legislativo como no âmbito jurisprudencial do STF. A título de exemplo de medidas legislativas tomadas é possível citar a Lei n. 8.038/1990 e a Lei

\footnotetext{
${ }^{12}$ Ibid. p. 963.
} 
9.756/1998. A primeira permitia ao relator deixar de admitir recurso se o Tribunal já tivesse pacificado a matéria; enquanto a segunda garantia ao relator a competência de decidir monocraticamente pelo provimento ou não do recurso extraordinário cuja matéria já estivesse pacificada na Corte.

No âmbito jurisprudencial, pode-se citar como exemplo o julgamento da ADI 4.071/DF, no qual a Corte entendeu pela manutenção da decisão agravada que havia indeferido a petição inicial, com fundamento no fato de que a norma questionada havia sido declarada constitucional em julgamento de recurso extraordinário anterior:

\begin{abstract}
"Manteve-se a decisão agravada no sentido do indeferimento da petição inicial, com base no dispositivo no art. $4^{\circ}$ da Lei 9.868/99, ante a manifesta improcedência da demanda, haja vista que a norma impugnada tivera sua constitucionalidade expressamente declarada pelo Plenário da Corte no julgamento do RE 377.457/PR (DJE de 19.12.2008) e do RE 381.964/MG (DJE de 26.9.2008). Vencidos, no mérito, os Ministros Marco Aurélio, Carlos Britto e Eros Grau, que proviam o recurso, ao fundamento de que precedentes versados a partir de julgamentos de recursos extraordinários não obstaculizariam uma ação cuja causa de pedir é aberta, em que o pronunciamento do Tribunal poderia levar em conta outros artigos da Constituição Federal, os quais não examinados nos processos subjetivos em que prolatadas as decisões e consubstanciarem os precedentes" 13 .
\end{abstract}

Seguindo a mesma linha de solução da crise numérica dos recursos extraordinários, a Emenda Constitucional n. 45, de 2004, criou o $§ 3^{\circ}$ para o artigo 102. Segundo esse dispositivo, o Supremo somente conhecerá o recurso extraordinário no qual o recorrente comprovar a existência de repercussão geral das questões constitucionais ali discutidas. Esse dispositivo constitucional foi regulado pela Lei 11.418/2006, que alterou o texto do Código de Processo Civil de 1973. As alterações feitas no antigo CPC foram mantidas no Novo Código de Processo Civil (Lei 13.105/2015), passando a figurar nos artigos 1.035 e 1.036 .

\footnotetext{
13 STF, Informativo $\quad$ n. 543. Disponível em http://www.stf.jus.br/arquivo/informativo/documento/informativo543.htm>. Acesso em 4 abr. 2017.
} 
Segundo a Lei 11.418, a repercussão geral é constituída por questões relevantes do ponto de vista econômico, político, social ou jurídico, que ultrapassam o interesse das partes envolvidas na causa.

A verificação da presença de repercussão geral deve ser feita nos moldes do artigo 323 do Regimento Interno do Supremo Tribunal Federal. Segundo esse dispositivo, o Presidente da Corte ou o Ministro Relator deve submeter sua manifestação ao Plenário Virtual acerca da existência, ou não, de repercussão geral no caso. Feito isso, determina o artigo 324 do RISTF, que os demais Ministros possuem o prazo de vinte dias para enviarem, por meio do Plenário Virtual, suas manifestações. Ademais, o mesmo Regimento Interno determina que se reputará repercussão geral ao recurso extraordinário se decorrer o prazo estabelecido e não houver manifestações suficientes em sentido contrário.

Reconhece-se, desta forma, que a sistemática do recurso extraordinário vem sofrendo diversas alterações no sentido de conceder contornos mais objetivos, distanciando-se um pouco do paradigma das causas subjetivas. Dessa forma, o Supremo já entendeu ser possível julgar a constitucionalidade de outras normas, ainda que não sejam do interesse do recorrente ${ }^{14}$. Ou seja, o Supremo tem assumido uma posição de que os recursos extraordinários que lhe compete julgar podem produzir efeitos para além das partes envolvidas no processo. Esse cenário é denominado objetivação do processo.

\subsubsection{Súmulas Vinculantes}

Além de processar e julgar (art. 102, CFRB), o Supremo também possui a competência para editar Súmulas Vinculantes, conforme estabelece o art. 103-A, que foi introduzido pela Emenda Constitucional n. 45/2004. Entretanto, a discussão para a criação de um instrumento que fixe determinado entendimento é muito anterior ao ano de 2004, e remonta até

${ }^{14}$ STF, RE n. 102.553/RJ, Rel. Min. Francisco Rezek, Brasília, 13 fev. 1987. 
os tempos do Império, quando, por meio do Decreto $\mathrm{n}^{\mathrm{o}}$ 2.684/1875, conferiu-se força de lei aos assentos da Casa de Suplicação de Lisboa e o Supremo Tribunal de Justiça passou a ter competência para tomar novos assentos.

Os assentos eram instrumentos que faziam com que o Poder Judiciário se aproximasse do Poder Legislativo, vez que possibilitava àquele determinar certa interpretação de uma norma que vinha sendo objeto de entendimentos discordantes.

Esse entendimento acerca dos assentos é importante para se compreender a afirmação com tom crítico de José Afonso da Silva:

"Os assentos eram, pois, as súmulas vinculantes de outrora, com a mesma força de lei, como uma força de interpretação oficial, impositiva, tal como as interpretações autênticas e, nesse sentido, subversivas dos princípios de direito público, já que interpretação oficial obrigatória só é legítima quando feita pelo Poder Legislativo""15.

Para uma Súmula Vinculante ser editada, revista ou cancelada é necessária decisão de dois terços dos Ministros (oito votos) nesse sentido. $\mathrm{O}$ Supremo pode editar uma súmula vinculante por iniciativa própria ou por provocação. Assim, o $\S 2^{\circ}$ do art. 103-A da Constituição estabelece que os legitimados para provocar o Supremo com respeito a Súmulas Vinculantes são os mesmos legitimados a propor a Ação Direta de Inconstitucionalidade. Entretanto, esse dispositivo não exclui que a legislação venha a determinar outros legitimados. Dessa forma, a Lei $\mathrm{n}$. 11.417/2006 estabelece, por meio de seu art. $3^{\circ}$, os legitimados para propor a edição, cancelamento ou a revisão de Súmulas Vinculantes.

Cumpre destacar que o inciso XI do artigo $3^{\circ}$ citado garante aos tribunais a legitimidade de provocar o Supremo em relação às Súmulas Vinculantes. Essa previsão é de suma importância porque permite àqueles que estão mais próximos da atividade jurisdicional participar do processo

\footnotetext{
${ }^{15}$ SILVA, José Afonso. Op. cit., p. 567
} 
de elaboração das súmulas vinculantes. Nesse sentido, Gilmar Mendes afirma que:

\begin{abstract}
"Parece altamente recomendável que dentre aqueles que venham a ser contemplados com essa legitimação, por decisão legislativa, estejam tribunais e juízes, uma vez que eles lidam, cotidianamente, com os processos que podem dar ensejo à formulação de súmulas"16.
\end{abstract}

A previsão de um instituto como a Súmula Vinculante está associada ao movimento de valorização da jurisprudência que ocorre no Direito brasileiro atualmente. Esse movimento surge por alguns motivos, como o aumento do número de ações judiciais e um número significativo de demandas tratando do mesmo objeto. Além desses dois motivos, o enaltecimento da jurisprudência está pautado num processo de valorização da atividade interpretativa do magistrado, isto é, a atividade de interpretação da norma passa a ser vista como processo complementar ao processo de criação do Direito e, por essa razão, interessa ao sistema jurídico que haja uma uniformização das decisões.

As Súmulas Vinculantes podem tratar da validade, da interpretação ou da eficácia de uma norma jurídica. Essa norma pode ser constitucional ou da legislação ordinária, podendo, ainda, ter sido produzida por qualquer um dos entes federativos.

Por meio da edição de uma Súmula Vinculante, o STF fixa seu entendimento a respeito de uma norma e determina que esse entendimento deve ser aplicado pela administração pública e pelos demais órgãos do Poder Judiciário, tornando inválido qualquer ato que lhe seja contrário.

Para uma Súmula Vinculante ser editada, revista ou cancelada é necessário decisão de dois terços dos Ministros (oito votos) nesse sentido. Além deste requisito, outra exigência para a edição de Súmulas Vinculantes é o posicionamento do STF em diversas ocasiões sobre a matéria, ou seja, é necessário que o Supremo tenha reiteradas decisões em um mesmo sentido sobre aquele assunto, o qual gera controvérsias judiciais relevantes entre

\footnotetext{
${ }^{16}$ MENDES, Gilmar Ferreira; BRANCO, Paulo Gustavo Gonet. Op. cit., p. 969
} 
órgãos judiciais ou entre esses e a administração pública (art. 103-A, §1º, CRFB). Portanto, há vedação expressa à edição de Súmula Vinculante fundada em decisão isolada do Supremo. É justamente em razão dessa exigência que críticas já foram feitas em relação ao uso das Súmulas Vinculantes pelo STF, principalmente, naquelas referentes ao uso das algemas (Súmula Vinculante n. 11) e do nepotismo (Súmula Vinculante n. 13), já que havia certa escassez de precedentes na Corte.

Em relação aos efeitos temporais, cumpre destacar que a Lei n. 11.417 estabelece que as Súmulas Vinculantes possuem efeitos imediatos $\left(\operatorname{art.} 4^{\circ}\right)$. Entretanto, essa regra pode ser excepcionada, como informa o dispositivo citado acima, mediante voto de dois terços dos Ministros, em razão de segurança jurídica ou de excepcional interesse público. Nesses casos excepcionais, os Ministros determinam que os efeitos das súmulas vinculantes só serão produzidos em um marco futuro.

Para potencializar a eficiência do instrumento, a Constituição estabelece, por meio do art. 103-A, $\S 3^{\circ}$, que cabe Reclamação ao Supremo contra decisão judicial ou ato administrativo que contrariar enunciado de Súmula Vinculante. Se o STF julgar a Reclamação procedente, o ato administrativo será anulado ou haverá a cassação da decisão judicial com a determinação de que outra seja proferida, tendo de observar o entendimento do Supremo sumulado.

Por outro lado, com o intuito de evitar uma crise numérica de Reclamações no Supremo, a Lei n. 9.784/99 estabelece algumas disposições acerca dos atos administrativos no âmbito da União para que sejam objeto de Reclamação dirigida ao STF. Assim, vale citar lição de Luís Roberto Barroso:

\footnotetext{
"Em primeiro lugar, a via de reclamação para o STF somente se abre após o esgotamento das instâncias administrativas. Em segundo lugar, nos recursos administrativos em que se alegue violação à súmula, a autoridade encarregada de decidir estará obrigada a expor as razões que a levam a considerar o enunciado aplicável ou inaplicável, conforme seja o caso. Por fim, uma vez proferida a reclamação, a autoridade administrativa será notificada para adequar sua conduta
} 
no caso em concreto e também nos subsequentes, sob pena de responsabilização pessoal" $"$.

Dessa maneira, é possível concluir que as Súmulas Vinculantes constituem instrumento importantíssimo para a Corte Suprema estabelecer seus entendimentos e torná-los de aplicação obrigatória pela administração pública e pelos demais órgãos do Poder Judiciário, havendo previsão, inclusive, de uma ação (a Reclamação) para preservar o entendimento sumulado.

17 BARROSO, Luís Roberto. O controle de constitucionalidade no direito brasileiro: exposição sistemática da doutrina e análise crítica da jurisprudência. $7^{\mathrm{a} e d . ~ S a ̃ o ~ P a u l o: ~ S a r a i v a, ~ 2016 . ~ p . ~} 114$. 


\section{Controle de constitucionalidade}

\subsection{O fenômeno da inconstitucionalidade}

No pensamento jurídico moderno, a Constituição é tida como norma suprema, servindo de fundamento para todas as outras normas. Essa supremacia é exercida sobre todas as pessoas, públicas ou privadas, vinculando, inclusive, o poder constituinte derivado e, claro, o legislador.

Assim, a teoria da inconstitucionalidade serve ao propósito de manter a Constituição como norma suprema, avaliando a validade das demais normas frente as disposições do texto constitucional. Dessa maneira, pode-se dizer que a teoria da inconstitucionalidade exerce um controle dos atos emanados dos órgãos públicos. Já os atos contrários à Constituição realizados por entes privados estão fora dos mecanismos de controle de constitucionalidade, sendo fiscalizados de maneira diferente.

O poder constituinte derivado e o legislador também estão vinculados ao disposto na Constituição. Essa vinculação ocorre tanto em relação à forma das leis e atos normativos como ao conteúdo que essas normas podem ter. Apesar desta vinculação, atos inconstitucionais ainda podem ser elaborados e relações jurídicas estabelecidas observando essas normas inconstitucionais. Visto isso, surge o questionamento sobre a localização de um ato inconstitucional dentro dos planos da existência, validade e eficácia.

\subsubsection{Os planos da existência, validade e eficácia}

Apesar de não ser muito comum no direito público, a análise dos planos da existência, validade e eficácia é de importância singular no estudo do fenômeno da inconstitucionalidade. 
A compreensão do plano da existência passa pelo entendimento do fenômeno conhecido como juridicização, isto é, o fenômeno que ocorre quando atos da vida social adentram o mundo jurídico. Isso ocorre nos casos em que uma manifestação no mundo dos fatos, por possuir elementos estabelecidos em lei, adentra o mundo do Direito. A respeito desses elementos, expõe Luís Roberto Barroso:

"É possível distinguir, dentre esses elementos, os que se poderiam dizer comuns, porque indispensáveis a qualquer ato jurídico (como agente, objeto e forma), e os que são específicos de determinada categoria de atos". ${ }^{18}$

Tendo em vista esse esclarecimento, aquela manifestação que não possuir os elementos determinados em lei não existe para o mundo jurídico. Seria o caso, por exemplo, de "uma lei que não houvesse resultado de aprovação da casa legislativa, por ausente a manifestação de vontade apta a fazê-la ingressar no mundo jurídico"19.

Um segundo plano é o da validade. Para se chegar a esse plano, o ato tem de ter os elementos constitutivos estabelecidos em lei, de maneira a passar pelo plano da existência. É no plano da validade que se deve verificar se os elementos do ato estão de acordo com o que a lei determina. Ou seja, não basta que exista um agente que realize o ato, ele deve ser competente para tanto; a forma deve estar de acordo com o estabelecido na lei, podendo ser verbal ou escrita, pública ou privada; não é suficiente que o ato possua um objeto, ele deve ser lícito e possível. Se um ato cumprir o que estiver estabelecido em lei em relação a seus elementos, ele será válido. Se houver algum descumprimento, o ato poderá ser nulo ou anulável.

A eficácia, como o próprio nome já indica, é a capacidade que o ato jurídico tem de produzir seus efeitos. Ou seja, uma vez verificada a presença dos elementos obrigatórios do ato, tornando-o existente e uma vez

\footnotetext{
${ }^{18}$ BARROSO, Luís Roberto. O controle de constitucionalidade no direito brasileiro: exposição sistemática da doutrina e análise crítica da jurisprudência. $7^{\mathrm{a}}$ ed. São Paulo: Saraiva, 2016. p. 34. ${ }^{19}$ Ibid., p. 35.
} 
verificado que os elementos do ato estão de acordo com o estabelecido em lei, o ato jurídico estará apto a produzir seus efeitos.

Frente a essas ideias, uma norma inconstitucional, seja em razão da sua forma ou de seu conteúdo, existe para o mundo jurídico; entretanto, não deve ser considerada válida, vez que não cumpriu o estabelecido na Constituição para a sua elaboração. Dessa maneira, essa norma inconstitucional é inválida, não podendo seguir adiante e chegar no plano da eficácia. Portanto, a norma inconstitucional, tendo sido reconhecido seu vício, não mais deve ser aplicada.

A norma que tem sua inconstitucionalidade reconhecida não deixa de existir. Ela é considerada inválida, mas passou pelo plano da existência. Por isso, que a declaração de inconstitucionalidade de um ato jurídico não deve ser confundida com sua revogação. A revogação implica a retirada da norma do mundo jurídico, sendo operada, portanto, no plano da existência. A revogação, em regra, ocorre por manifestação do órgão que elaborou o ato que se quer revogar e seus efeitos operam daquele momento em diante (ex nunc). Já a declaração de inconstitucionalidade é feita, via de regra, pelo Judiciário e seus efeitos são ex tunc, isto é, retroagem.

\subsubsection{Nulidade da norma inconstitucional}

Como exposto anteriormente nesse capítulo, uma norma inconstitucional é inválida, portanto, não produz efeitos. O raciocínio é razoável: como a Constituição é a norma suprema do país, não há como se admitir que uma norma incoerente com ela produza quaisquer efeitos.

Esse entendimento prevaleceu na doutrina americana e foi recepcionado pela doutrina brasileira. Entretanto, já não se trata de um conceito absoluto, sofrendo algumas atenuações, conforme ilustra Barroso:

\footnotetext{
"Ao longo do tempo, a jurisprudência do Supremo Tribunal Federal fez alguns temperamentos à aplicação rígida dessa tese, e, já agora, a Lei n. 9.868, de 10 de
} 
novembro de 1999, ampliou a competência discricionária da Corte relativamente à pronúncia de nulidade e o consequente caráter retroativo da decisão" 20 .

Portanto, é possível concluir que a norma inconstitucional existe, mas não é válida. Entretanto, como essa norma adentrou o ordenamento jurídico, relações podem ter sido constituídas com base nela. Dessa forma, em casos de excepcional interesse social ou de segurança jurídica, admitese a restrição dos efeitos da declaração de inconstitucionalidade, determinando que os efeitos da decisão não serão ex tunc.

\subsection{Leading case: Marbury v. Madison}

Esse é o primeiro julgado em que a Suprema Corte Americana exerceu seu poder de controle de constitucionalidade. Para entender o caso é fundamental conhecer a conjuntura política americana à época.

Nas eleições realizadas em 1800, o partido federalista, do então presidente John Adams, foi derrotado, tanto no Legislativo como no Executivo, pelo partido republicano, que tinha Thomas Jefferson como candidato a presidente.

Antes de deixar a presidência, Adams e o Congresso, que ainda era controlado pelos federalistas, elaboraram uma série de reformas para que mantivessem sua influência por meio do Poder Judiciário. Nesse sentido, o the Circuit Court Act foi elaborado e aprovado, estabelecendo uma reorganização do Judiciário federal americano. Por meio dessa lei, estabelecia-se a diminuição do número de juízes da Suprema Corte, de maneira a evitar que o recém-eleito presidente Jefferson nomeasse algum juiz para a Corte; também ficou estabelecida a criação de dezesseis novos cargos de juiz federal, que deveriam ser preenchidos por quem Adams nomeasse.

Ainda com o intuito de realizar uma reforma no Judiciário para manter a influência política do partido federalista, o Congresso elaborou

\footnotetext{
${ }^{20}$ Ibid., p. 40.
} 
uma nova lei (the Organic Act of the District of Columbia) que autorizava John Adams a nomear quarenta e dois juízes de paz. Os nomes para preencher esses novos cargos foram indicados e aprovados pelo Senado no último dia de presidência de Adams. Portanto, apenas no último dia de sua presidência, Adams assinou os instrumentos de investidura dos juízes (comissions). $\mathrm{O}$ encarregado de entregar todos esses atos aos novos juízes de paz foi John Marshall, que era Secretário de Estado do presidente e havia sido nomeado por ele para a Suprema Corte, mas ficou até o último dia da presidência de Adams exercendo o cargo de Secretário de Estado. Como Marshall teve apenas um dia para entregar todos os comissions, nem todos os juízes nomeados por Adams receberam suas nomeações.

No dia seguinte, Jefferson tomou posse e orientou seu Secretário de Estado, James Madison, no sentido de não entregar os atos de investidura que não haviam sido entregues por Marshall. Entre os juízes que não receberam o comission estava William Marbury, que, insatisfeito com a decisão do Presidente e de seu Secretário de Estado, propôs uma ação judicial (writ of mandamus) perante a Suprema Corte.

Cumpre ressaltar que os Estados Unidos viviam um período de muita tensão. Não só havia todo esse imbróglio envolvendo o ex-presidente John Adams e o novo presidente Thomas Jefferson, havia também uma substancial tensão entre o Congresso americano e a Suprema Corte. Dentro desse cenário de inquietude, o Congresso, que já era dominado pela maioria republicana, revogou o the Circuit Court Act, destituindo os juízes federais que haviam sido investidos nos cargos pelo presidente Adams e impediu que a Suprema Corte se reunisse de dezembro de 1801 até fevereiro de 1803, com intuito de evitar questionamentos sobre sua decisão.

Além de toda essa tensão, Thomas Jefferson indicava que não consideraria legítima e, portanto, não cumpriria qualquer decisão da Suprema Corte que ordenasse a entrega dos atos de investidura aos juízes de paz indicados por John Adams. 
Era em meio a toda essa tensão política envolvendo os três Poderes dos Estados Unidos que a Suprema Corte deveria julgar a ação proposta por William Marbury. Essa conjuntura não era apenas um quadro que tornava a situação delicada, ela acabaria por influenciar o teor da decisão da mais alta Corte do sistema judiciário americano.

Como demonstra o título deste subcapítulo, Marbury v. Madison foi o caso que fundou o controle de constitucionalidade no Direito moderno. Entretanto, não foi Marshall quem concebeu a ideia completa do judicial review. Essa ideia já era objeto de decisões dentro do próprio Estados Unidos na época colonial, e também já era objeto de decisões de cortes estaduais e cortes federais inferiores ${ }^{21}$.

A Constituição norte-americana não possuía nenhuma previsão explícita estabelecendo a Suprema Corte ou qualquer outro órgão do Judiciário como competente para exercer o controle de constitucionalidade.

\footnotetext{
${ }^{21} \mathrm{Na}$ clássica obra "O controle judicial de constitucionalidade das leis no direito comparado", Mauro Cappelletti identifica precedentes do judicial review instituído nos Estados Unidos. O autor indica referências exemplificativas de sistemas anteriores a 1787 que estabeleciam a supremacia de uma determinada norma ou de um corpo de normas (o que corresponderia, nos dias atuais, a normas constitucionais) em relação a outras normas (que corresponderiam, atualmente, às leis ordinárias).
}

O primeiro exemplo citado por Cappelletti remonta à época da antiga civilização ateniense, na qual havia dois tipos de normas: nómos e pséfisma. O nómos prevalecia sobre um pséfisma se houvesse divergência entre as normas.

O segundo exemplo reporta-se à Idade Média, que, por estar intimamente conectada à doutrina tomista, aos filósofos do estoicismo e às ideias de Cícero, considerava o direito natural como norma superior ao direito positivo. Assim, as normas de direito natural eram superiores e inderrogáveis e deveriam prevalecer sobre as normas de direito positivo.

O último exemplo dado por Mauro Cappelletti diz respeito ao precedente imediato do judicial review. Este precedente remonta ao século XVII, quando Sir Edward Coke defendeu a ideia da supremacia do common law em relação à statute law e ao custom. Além disso, Coke defendia que o responsável por proteger a supremacia do common law contra os arbítrios do Rei e do Parlamento seria o Poder Judiciário. Essa ideia predominou por algumas décadas na Inglaterra e nas colônias inglesas. Todavia, essa doutrina foi abandona pelo Reino inglês com a Revolução Gloriosa de 1688, mas os frutos dela permaneceram pelo menos na América.

A ideia de Coke chegou às colônias inglesas. Essas colônias eram regidas por Cartas (que poderiam ser consideradas como as constituições das colônias, pois eram vinculatórias ao legislador colonial e regulavam estruturas jurídicas fundamentais) as quais estabeleciam que as colônias poderiam aprovar suas próprias leis, mas elas só seriam válidas e aplicáveis se não estivessem contrárias às leis do Reino da Inglaterra. Essas Cartas, a partir da independência das colônias, foram substituídas por constituições, as quais deveriam prevalecer sobre leis que a elas fossem contrárias. 
Portanto, ao analisar o caso, John Marshall necessitava explicar que a atuação da Suprema Corte (agindo como controlador da constitucionalidade de leis) era decorrência lógica do sistema instituído pela norma suprema. Para tanto, invocou o estabelecido no art. VI, cláusula $2^{\mathrm{a}}$, da Constituição de 1787, que estipulava que "this Constituition (...) shall be the supreme Law of the Land; and the judges in every State shall be bound thereby". Segundo o entendimento de Marshall, esse dispositivo constitucional instituía o poder dos juízes para deixar de aplicar leis que entendessem como contrárias à Constituição.

Ao elaborar seu voto, Marshall o dividiu em três partes, sendo que na última havia duas perguntas a serem respondidas. Na primeira parte, o juiz reconheceu que Marbury possuía o direito objeto da ação ${ }^{22}$. A segunda parte foi dedicada à demonstração de que, já que havia um direito subjetivo, deveria existir um remédio para assegurá- $-\mathrm{l}^{23}$. Já na terceira parte, Marshall buscou responder a dois questionamentos: se o writ of mandamus era o meio correto para buscar o direito à investidura no cargo (para isso, avalia a natureza da ação proposta) e se a Suprema Corte era o órgão competente para conceder esse direito ${ }^{24}$.

Marshall entendeu que o writ of mandamus era o meio adequado para Marbury buscar seu direito, uma vez que esse instrumento - que é similar mas não igual ao mandado de segurança - consiste na determinação a uma instância inferior ou a uma autoridade pública ou privada que

${ }^{22}$ MARBURY V. MADISON, 5 U.S. (1 Cranch) 137 (1803): "1. That, by signing the commission of Mr. Marbury, the President of the United States appointed him a justice of peace for the County of Washington in the District of Columbia, and that the seal of the United States, affixed thereto by the Secretary of State, is conclusive testimony of the veruty of the signature and of the completion of the appointment, and that the appointment conferred on him a legal right to the office for the space of five years". Disponível <https://www.law.cornell.edu/supremecourt/text/5/137\#writing-USSC_CR_0005_0137_ZS>. Acesso em: 23 abr. 2017.

${ }^{23}$ MARBURY V. MADISON, 5 U.S. (1 Cranch) 137 (1803): "2. That, having this legal title to the office, he has the consequent right to the commission, a refusal to deliver which is a plain violation of that right, for wich the laws of his country afford him a remedy". Disponível em: https://www.law.cornell.edu/supremecourt/text/5/137\#writing-USSC_CR_0005_0137_ZS>.

Acesso em 23 abr. 2017.

${ }^{24}$ MARBURY V. MADISON, 5 U.S. (1 Cranch) 137 (1803): "He is entitled to the remedy for which he applies. This depends on: 1 . The nature of the writ applied for, and 2 . The power of this court". Disponível em: <https://www.law.cornell.edu/supremecourt/text/5/137\#writingUSSC_CR_0005_0137_ZS>. Acesso em 23 abr. 2017. 
conceda um direito estabelecido em lei. Ao enfrentar essa questão, Marshall demonstrou que os atos do Poder Executivo são passíveis de controle por parte do Poder Judiciário, com exceção dos atos de natureza política e daqueles aos quais a lei atribui discricionariedade.

Vista e respondida a primeira questão da terceira parte do voto, Marshall passou a responder ao questionamento sobre a competência da Suprema Corte para expedir um mandado (writ) para que o Executivo concedesse o direito a William Marbury. Ao analisar esse ponto, o juiz da Suprema Corte entendeu que o $\$ 13$ da Lei Judiciária de 1789 era inconstitucional por atribuir uma nova competência originária à Corte que não estava prevista na Constituição.

Importante notar que, ao elaborar sua decisão, Marshall inverteu a ordem processual lógica, iniciando sua análise pelo mérito da questão, para depois analisar uma questão preliminar. Essa estrutura foi estabelecida propositalmente em razão da crise política dos Estados Unidos. Foi a forma encontrada pelo juiz para elaborar um julgado impossível de ser descumprido pelo presidente Jefferson. Se o presidente escolhesse não entregar o ato de investidura a Marbury, ele estaria cumprindo a decisão da Suprema Corte, pois ela não havia expedido o writ para isso. Mas também cumpriria a decisão se resolvesse entregar o instrumento de posse, pois Marshall havia reconhecido o direito de Marbury assumir o cargo de juiz de paz.

Portanto, o caso Marbury v. Madison foi o leading case responsável por consolidar o controle de constitucionalidade no constitucionalismo moderno. Esse caso serviu para enraizar o princípio da supremacia da Constituição, estabelecendo que todas as normas e Poderes estão a ela vinculados.

\subsection{As modalidades de controle}


Como visto anteriormente, o caso Marbury v. Madison, decidido em 1803, foi o responsável por consolidar o controle de constitucionalidade no constitucionalismo moderno. Durante os mais de duzentos anos que se passaram, o controle de constitucionalidade foi objeto de diversos estudos e apresentou uma incrível evolução, passando a comportar outras modalidades diversas daquela apresentada na principal decisão da história do constitucionalismo.

Na doutrina, é possível classificar o controle de cinco maneiras:

\section{1 - Quanto ao momento}

\section{A - Controle prévio}

Por essa modalidade de controle, a norma não entra em vigor, ela é analisada em momento anterior à sua promulgação. No Brasil, essa modalidade é exercida, em regra, pelo Poder Legislativo e pelo Poder Executivo. O Legislativo atua por meio de suas Comissões de Constituição e Justiça que, normalmente, se pronunciam a respeito da constitucionalidade de um projeto no início do processo legislativo. O Poder Executivo pratica essa modalidade de controle por meio do veto, que possui como uma de suas justificativas a inconstitucionalidade do projeto aprovado pelo Legislativo ${ }^{25}$. Além dessas hipóteses, há uma outra de caráter excepcional, qual seja, o controle prévio realizado pelo Supremo Tribunal para os casos de mandado de segurança impetrado por parlamentar contra deliberação do Legislativo acerca de projeto que seja contrário às cláusulas pétreas.

\section{B - Controle repressivo}

\footnotetext{
${ }^{25}$ O Legislativo atua no controle prévio por meio de suas Comissões de Constituição e Justiça, as quais, conforme o art. $52, \S 2^{\circ}$, I da Constituição, podem votar projetos de lei. Assim, na forma do regimento interno de cada Casa Legislativa (art. 32, IV, a, do Regimento Interno da Câmara dos Deputados; e art. 101, I, do Regimento Interno do Senado Federal) o Poder Legislativo exerce o controle de constitucionalidade prévio. Já o Poder Executivo exerce essa modalidade de controle por meio do veto previsto pelo art. $66, \S 1^{\circ}$ da Constituição.
} 
O controle repressivo é aquele realizado em momento posterior àquele que a norma entra em vigor. Em regra, essa modalidade de controle é exercida pelo Poder Judiciário, entretanto há hipóteses em que o Legislativo (por exemplo: quando esse Poder susta atos normativos exorbitantes editados pelo Poder Executivo ${ }^{26}$ ) e o Executivo (por exemplo: quando há a recusa por parte da Administração Pública de aplicar lei que entende por inconstitucional, embora essa decisão seja controversa) exercem controle repressivo.

\section{2 - Quanto ao órgão controlador}

\section{A - Controle político}

Essa modalidade de controle de constitucionalidade indica que um órgão dessa natureza é responsável pelo exercício do controle de constitucionalidade. No Brasil, essa espécie de controle pode ser verificada, por exemplo, quando o Poder Legislativo, por meio de sua Comissão de Constituição e Justiça entende o projeto como inconstitucional; e também quando o chefe do Poder Executivo exerce seu poder de veto por entender uma norma como inconstitucional.

Ainda em relação à experiência brasileira, interessante lembrar que a Constituição de 1824 previa apenas o controle político. Essa modalidade de controle de constitucionalidade era exercida pela Assembleia Geral, vez que era ela competente para fazer, interpretar, suspender ou revogar leis (art. 15, VIII) e cabia a ela a guarda da Constituição (art. 15, IX). Cumpre sempre lembrar que na Constituição do Império, o Poder Moderador, exercido pelo Imperador, detinha o poder de veto suspensivo em relação aos atos da Assembleia.

\section{B - Controle judicial}

\footnotetext{
${ }^{26} \mathrm{O}$ art. 49, V da Constituição confere a competência ao Congresso Nacional de sustar atos do Poder Executivo que exorbitem seu poder regulamentar ou que ultrapasse os limites da delegação legislativa.
} 
Esse gênero de controle de constitucionalidade foi estabelecido no constitucionalismo moderno pela decisão da Suprema Corte americana no caso Marbury v. Madison. Até esse momento, havia uma grande discussão a respeito da legitimidade do Poder Judiciário para realizar o controle de constitucionalidade. Em razão dessa polêmica o Juiz John Marshall teve de justificar em seu voto que, por ser papel do Judiciário interpretar a Constituição e por ela ser a lei suprema da nação, qualquer norma que fosse incompatível com ela seria nula (void) e caberia aos Juízes e Tribunais decidir sobre isso, já que estariam diante da questão de qual norma aplicar, a Constituição ou uma lei que lhe seja contrária ${ }^{27}$.

No Brasil, o sistema de controle de constitucionalidade é, em regra, exercido pelo Judiciário, com algumas hipóteses sendo de competência de órgãos políticos.

\section{3 - Quanto à forma}

\section{A - Controle formal}

Nesta modalidade de controle de constitucionalidade há a verificação se a norma está de acordo com o processo legislativo que a Constituição estabelece (arts. 59 a 69).

\section{B - Controle material}

Por meio do controle material de constitucionalidade, verifica-se se o conteúdo de uma determinada norma está em conformidade com o estabelecido no texto constitucional.

\footnotetext{
${ }^{27}$ Essa é a tese defendida por Alexander Hamilton, no art. 78 dos "Federalistas". Hamilton escreve: "A integral independência das cortes de justiça é particularmente essencial em uma Constituição limitada. Ao qualificar uma Constituição como limitada, quero dizer que ela contém certas restrições específicas à autoridade legislativa, tais como, por exemplo, não aprovar projetos de confiscos, leis ex post facto e outras similares. Limitações dessa natureza somente poderão ser preservadas na prática através das cortes de justiça, que têm o dever de declarar nulos todos os atos contrários ao manifesto espírito da Constituição. Sem isso, todas as restrições contra privilégios ou concessões particulares serão inúteis." Disponível em < https://docs.google.com/viewer?a=v\&pid=sites\&srcid=ZGVmYXVsdGRvbWFpbnxkb3dubG9hZ GNvbnRldWRvc2RpcmVpdG98Z3g6MTU1MGIzMzA2NDZkNGRmNw>. Acesso em 30 jun. 2017.
} 


\section{4 - Quanto ao órgão judicial}

\section{A - Controle difuso}

O controle de constitucionalidade é tido como difuso quando qualquer juiz ou tribunal pode exercê-lo. Esse modelo teve início no caso Marbury v. Madison, no qual ficou estabelecido o papel do Poder Judiciário, como já exposto aqui, de interpretar normas jurídicas. Nesse exercício de interpretação, o magistrado pode deixar de aplicar uma norma por entende-la como conflitante com a Constituição.

Portanto, o controle é tido como difuso por ele estar disseminado por todo o Poder Judiciário, podendo ser exercido por um juiz de primeira instância até o Supremo Tribunal Federal.

\section{B - Controle concentrado}

Diz-se que o controle é concentrado por ser exercido por um órgão ou por um número limitado deles que possuem o controle de constitucionalidade como função específica. Esse modelo nasceu na constituição austríaca de 1920 e foi difundido amplamente pelo resto da Europa.

Esse modelo foi introduzido no Direito brasileiro pela Emenda Constitucional n. 16, de 1965. Por meio dessa Emenda, ficou estabelecida a competência do Supremo Tribunal Federal, mediante representação do Procurador-Geral da República, para realizar essa espécie de controle de constitucionalidade. Importante ressaltar que já existia no Direito brasileiro ação de competência concentrada do STF, qual seja, a representação interventiva, criada pela Constituição de 1934, que era uma ação que deveria ser julgada pelo Supremo para que houvesse intervenção federal em um Estado.

\section{5 - Quanto às vias}




\section{A - Controle por via incidental (concreto)}

Nesta modalidade, o juiz, ao realizar sua função jurisdicional, se depara com um questionamento sobre a constitucionalidade de uma norma. Portanto, para resolver o caso concreto do qual está diante, o juiz precisa avaliar a constitucionalidade de uma norma, isto é, a constitucionalidade da norma é questão prejudicial para o caso concreto que o magistrado está julgando.

Esse gênero de controle de constitucionalidade é chamado também de via de exceção, pois, por vezes, a questão constitucional é levantada pela parte ré como técnica de defesa. Entretanto, a questão constitucional pode ser suscitada de ofício ou pela parte autora, tornando o termo "via de exceção" algo questionável.

O controle por via incidental não deve ser confundido com o controle difuso. Em regra, no Direito brasileiro, eles se sobrepõem. Entretanto, a Lei 9.982/99 criou a arguição de descumprimento de preceito fundamental, elaborando um caso de controle incidental concentrado.

\section{B - Controle por via de ação (abstrato)}

Esse modelo decorre do controle concentrado difundido pela Europa. Nessa espécie de controle, não se busca tutelar direitos subjetivos, como ocorre no controle por via incidental. No controle por via de ação, a norma é objeto da ação e tem sua constitucionalidade avaliada em abstrato, sem que se considere um caso concreto específico.

\subsection{Sistema brasileiro de controle de constitucionalidade}

O sistema brasileiro de controle de constitucionalidade se desenvolveu profundamente, de maneira a se estabelecer uma estrutura complexa, deixando para trás o entendimento de ser constituído pela junção dos modelos concreto e difuso com abstrato e concentrado. Atualmente, os 
modelos se comunicam, isto é, não há um isolamento do modelo de controle concreto-difuso para o abstrato-concentrado. Essa comunicação pode ser exemplificada pela Ação Declaratória de Constitucionalidade, que possui como pressuposto para seu ajuizamento controvérsia judicial relevante (art. 14, III, Lei 9.868/99).

Esse modelo complexo não foi implementado de maneira instantânea, nem sequer de uma constituição para outra. Dessa forma, é preciso compreender todo o desenvolvimento histórico pelo qual o controle de constitucionalidade passou no Direito brasileiro.

\subsubsection{Desenvolvimento histórico do sistema brasileiro}

\subsubsection{Constituição do Império do Brasil (1824) ${ }^{28}$}

A primeira constituição brasileira estabelecia o Poder Legislativo como o responsável pela guarda da constituição e pela interpretação das leis. Ademais, o texto constitucional previa o Poder Moderador, que era o responsável pela manutenção da harmonia entre os demais poderes.

Assim, a instituição de um modelo de controle de constitucionalidade esbarrava nesses dois elementos. Não haveria possibilidade de existir esse controle com o Poder Legislativo sendo o responsável pela interpretação das normas que ele mesmo criava e com a existência do Poder Moderador, que, na prática, estava acima dos demais Poderes.

\subsubsection{Constituição de $1891^{29}$}

\footnotetext{
28 Constituição Política do Império do Brazil (1824). Disponível em < http://www.planalto.gov.br/ccivil_03/constituicao/constituicao24.htm>. Acesso em 27 abr. 2017. 29 Constituição da República dos Estados Unidos do Brasil (1891). Disponível em < http://www.planalto.gov.br/ccivil_03/constituicao/constituicao91.htm>. Acesso em 28 abr. 2017
} 
A primeira Constituição brasileira republicana foi fortemente influenciada pelo direito norte-americano. Muito em razão dessa influência, ficou instituído o controle de constitucionalidade difuso no ordenamento brasileiro. Segundo o art. 59, $\S 1^{\circ}$, cabia ao Supremo Tribunal Federal julgar recurso, em última instância, em duas ocasiões:

"Art 59 - Ao Supremo Tribunal Federal compete:

$\S 1^{\circ}$ - Das sentenças das Justiças dos Estados, em última instância, haverá recurso para o Supremo Tribunal Federal:

a) quando se questionar sobre a validade, ou a aplicação de tratados e leis federais, e a decisão do Tribunal do Estado for contra ela;

b) quando se contestar a validade de leis ou de atos dos Governos dos Estados em face da Constituição, ou das leis federais, e a decisão do Tribunal do Estado considerar válidos esses atos, ou essas leis impugnadas".

Assim, com o dispositivo constitucional citado acima, ficou estabelecido que a justiça federal e as justiças estaduais eram competentes para julgar a legitimidade de uma norma frente a Constituição, cabendo recurso contra essas decisões ao Supremo. Portanto, a Constituição brasileira de 1891 estabeleceu de maneira expressa aquilo que havia sido construído por via jurisprudencial no Direito dos Estados Unidos.

O modelo difuso implementado no Direito brasileiro pela primeira Constituição republicana foi reforçado pela edição da Lei n. 221, como mostra o art. $13, \S 10$ :

\footnotetext{
"Art. 13. Os juizes e tribunaes federaes processarão e julgarão as causas que se fundarem na lesão de direitos individuaes por actos ou decisão das autoridades administrativas da União.

$\S 10$. Os juizes e tribunaes apreciarão a validade das leis e regulamentos e deixarão de applicar aos casos occurrentes as leis manifestamente inconstitucionaes e os regulamentos manifestamente incompativeis com as leis ou com a Constituição".
}

Foi, portanto, dessa maneira que se estabeleceu o controle de constitucionalidade no Direito brasileiro. Como é possível notar, o controle estabelecido pela Constituição era difuso e concreto, inexistindo ainda qualquer previsão de uma atuação do Poder Judiciário em abstrato. 


\subsubsection{Constituição de $1934^{30}$}

Após a Revolução de 1930 e grandes protestos pela convocação de uma Assembleia Constituinte, a Constituição de 1934 foi promulgada. Essa Constituição manteve, por meio de seu art. 76, 2, III, b e c., a competência do Supremo Tribunal Federal (chamado de Corte Suprema) determinada na Constituição de 1891.

Por outro lado, a Constituição de 1934 trouxe significativas mudanças no sistema de controle de constitucionalidade. Uma dessas inovações importantes foi a determinação de que os Tribunais somente poderiam declarar a inconstitucionalidade de uma norma se a maioria absoluta de seus magistrados membros se posicionasse neste sentido (art. 179).

Outra inovação importantíssima instituída no texto constitucional de 1934 foi a atribuição ao Senado Federal da competência "para suspender a execução, no todo ou em parte, de qualquer lei ou ato, deliberação, ou regulamento, quando hajam sido declarados inconstitucionais pelo Poder Judiciário" (art. 91, IV). Assim, ficou introduzido um mecanismo para se conceder efeito erga omnes à decisão da Corte Suprema sobre a inconstitucionalidade de uma norma que, em regra, produziria apenas efeito entre as partes do processo. Essa inovação da Constituição de 1934 é mantida pelo texto constitucional de 1988 , por meio do art. 52 , X, o que suscita grandes discussões atualmente.

A Constituição de 1934 implementou um mecanismo de controle de constitucionalidade bastante interessante referente à lei que tratasse de intervenção federal, a qual poderia ser editada com o intuito de resguardar os princípios constitucionais previstos nas alíneas a $a \mathrm{~h}$, do art. $7^{\circ}$. A edição

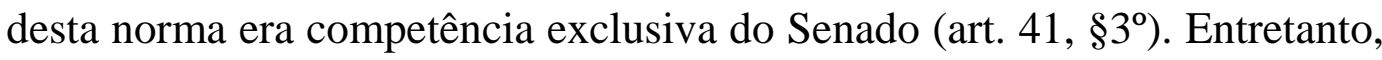
para a aplicação desta lei, não bastava sua aprovação no processo

\footnotetext{
30 Constituição da República dos Estados Unidos do Brasil (1934). Disponível em <
} http://www.planalto.gov.br/ccivil_03/constituicao/constituicao34.htm>. Acesso em 28 abr. 2017. 
legislativo comum. O texto constitucional determinava que uma lei de intervenção federal devia ter sua constitucionalidade avaliada pela Corte Suprema depois de provocação pelo Procurador-Geral da República (art. $\left.12, \S 2^{\circ}\right)$. Portanto, a aplicação de uma lei interventiva, que devia ser elaborada pelo Senado, só seria possível depois de ter sua constitucionalidade verificada pela Corte Suprema.

Trata-se do primeiro instrumento de controle concentrado no Direito brasileiro. Contudo, esse mecanismo ainda era muito limitado, servindo apenas para avaliar a lei editada pelo Senado que pretendia consumar a intervenção federal.

Observa-se que, apesar da Constituição de 1934 não ter uma extensão temporal significativa, ela foi responsável pela introdução de importantes inovações no sistema de controle de constitucionalidade no Brasil, com algumas delas sendo previstas pela Constituição de 1988.

\subsubsection{Constituição de $1937^{31}$}

A Constituição de 1937 foi a primeira a ter caráter autoritário na história republicana brasileira. Ela ficou conhecida como Constituição Polaca, como já foi exposto no capítulo anterior que tratou do Supremo Tribunal Federal (Capítulo 2. 2. 2) .

Em relação ao controle de constitucionalidade, a quarta constituição brasileira foi responsável por um retrocesso. De fato, ficou mantida a exigência de maioria absoluta de votos para a declaração de inconstitucionalidade, por meio do art. 96, como já havia feito a Constituição de 1934 (art. 179).

A inovação da Constituição autoritária, por sua vez, venho por meio do parágrafo único do artigo 96. Esse dispositivo instituiu um mecanismo de reavaliação da decisão sobre a inconstitucionalidade de uma norma

\footnotetext{
31 Constituição dos Estados Unidos do Brasil (1937). Disponível em < http://www.planalto.gov.br/ccivil_03/constituicao/constituicao37.htm>. Acesso em 28 abr. 2017.
} 
emanada por um Tribunal. Por meio do parágrafo único do artigo 96, uma norma julgada inconstitucional pelo Tribunal mas entendida pelo Presidente como necessária "ao bem-estar do povo, à promoção ou defesa de interesse nacional de alta monta" poderia ser submetida novamente ao Parlamento. O Congresso poderia confirmar a lei por manifestação de dois terços de seus membros, deixando sem efeitos a declaração de inconstitucionalidade emitida pelo Tribunal. Dessa forma, é possível dizer que, se a norma declarada inconstitucional fosse confirmada pelo Parlamento, ela passaria a ter na realidade força de emenda à Constituição.

\subsubsection{Constituição de $1946^{32}$}

A Constituição de 1946 foi a responsável por restituir uma ordem democrática no Brasil, superando o período ditatorial da Era Vargas.

Em relação ao controle de constitucionalidade, o texto constitucional de 1946 representou uma retomada da tradição brasileira sobre o tema: o art. 200 manteve a exigência de manifestação da maioria absoluta dos membros de um Tribunal para declarar uma norma inconstitucional; havia a previsão constitucional para o Supremo realizar o controle de constitucionalidade concreto, via recurso extraordinário, sem que sua decisão fosse reavaliada pelo Presidente ou pelo Congresso, como ocorria na Constituição anterior; previu novamente, por meio do art. 64, a atuação do Senado Federal para conceder efeito erga omnes à decisão de inconstitucionalidade do STF.

O texto constitucional de 1946 foi responsável por uma reestruturação do controle de constitucionalidade relativo à intervenção federal, que havia sido implementado pela Constituição de 1934. Com a nova Constituição, a intervenção federal poderia ser decretada em razão da violação de alguns princípios, como estabelecia o artigo $8^{\circ}$. O parágrafo

32 Constituição dos Estados Unidos do Brasil (1946). Disponível em <http://www.planalto.gov.br/ccivil_03/constituicao/constituicao46.htm>. Acesso em 28 abr. 2017. 
único deste artigo estabelecia também que o Supremo deveria decretar a inconstitucionalidade do ato que ensejaria a intervenção após ser provocado pelo Procurador-Geral da República.

O modelo de controle de constitucionalidade em relação à intervenção federal atribuía competência para o Supremo avaliar uma norma em abstrato, mas ainda sobre um conteúdo limitado. O controle de constitucionalidade em abstrato foi aprofundado com a Emenda Constitucional n. 16, de 1965.

A Emenda n. 16, de 26 de novembro de 1965 instituiu o controle de constitucionalidade abstrato para leis federais, tomando como modelo o controle de leis estaduais no julgamento de intervenção federal. Assim, o art. 101, I, k passou a prever a possibilidade de o Procurador-Geral da República encaminhar representação de inconstitucionalidade de norma federal ou estadual ao Supremo Tribunal Federal, cabendo ao Pleno da Corte o julgamento. Dessa forma, a Constituição de 1946, em razão da Emenda n. 16, passou a consagrar o modelo de controle abstratoconcentrado.

Ademais, cumpre destacar que a Emenda n. 16 alterou o art. 124, XIII, de maneira que a Constituição passasse a prever a possibilidade de uma lei poder estabelecer o processo para julgamento de lei municipal em conflito com Constituição Estadual. O julgamento dessa ação caberia originariamente ao Tribunal de Justiça do Estado.

Portanto, a partir de 1965, a ordem jurídica brasileira consagrou uma reunião dos modelos concreto-difuso e abstrato-concentrado.

\subsubsection{Constituição de $1967^{33}$ e a Emenda Constitucional n. 1 de $1969^{34}$}

\footnotetext{
33 Constituição da República Federativa do Brasil (1967). Disponível em <http://www.planalto.gov.br/ccivil_03/constituicao/constituicao67.htm>. Acesso em 28 abr. 2017. 34 Emenda Constitucional $n^{o} 1$, de 17 de outubro de 1969. Disponível em < http://www.planalto.gov.br/ccivil_03/Constituicao/Emendas/Emc_anterior1988/emc01-69.htm>. Acesso em 28 abr. 2017.
} 
A Constituição de 1967 não trouxe mudanças significativas no controle de constitucionalidade. Ela manteve a ação direta nos mesmos moldes estabelecidos pela Emenda n. 16, de 1965.

O controle sobre a intervenção federal sofreu mudanças moderadas. O Procurador-Geral da República permaneceu como o competente para propor a ação de representação com o intuito de intervenção. Todavia, esse instrumento teve sua aplicação ampliada, cabendo a intervenção federal não apenas para assegurar princípios (art. 10, VII), como também para providenciar a execução de lei federal (art. 10, VI, $1^{\mathrm{a}}$ parte). A competência para avaliar o ato estadual deixou de pertencer ao Supremo, como estabelecia a Constituição de 1946, passando para a esfera de competências do Presidente da República.

Em relação ao controle de constitucionalidade de leis municipais, a Constituição de 1967 não acolheu as mudanças introduzidas no sistema brasileiro pela Emenda n.16/1965. O procedimento de controle das leis municipais só passou a ser previsto novamente com a Emenda n. 1/1969 (art. 15, I, §3 $\left.3^{\circ}, \mathrm{d}\right)$.

Por último, cumpre destacar previsão instituída pela Emenda n. 7/77 e que permanece no ordenamento jurídico pátrio até os dias atuais, qual seja, a possibilidade de pedido liminar em representação de inconstitucionalidade. A Emenda n. 7 previa a possibilidade de um pedido cautelar nas ações propostas pelo Procurador-Geral da República, que deveria ser julgado pelo Supremo (art. 119, I, p). Essa previsão permanece no ordenamento jurídico brasileiro até hoje, sendo contemplada pela Constituição de 1988 (art. 102, I, p).

\subsubsection{O sistema judicial de controle na Constituição de $1988^{35}$}

\footnotetext{
35 Constituição da República Federativa do Brasil de 1988. Disponível em <http://www.planalto.gov.br/ccivil_03/constituicao/constituicaocompilado.htm>. Acesso em 29 abr. 2017.
} 
Percebe-se, pela análise do desenvolvimento histórico do controle judicial, que o sistema brasileiro nasceu como concreto-difuso. Posteriormente, com a Constituição de 1934, instituiu-se o controle concentrado referente à intervenção federal. Somente no ano de 1965, com a Emenda n. 16, o ordenamento brasileiro incorporou completamente o controle abstrato-concentrado.

Com o advento da Constituição de 1988, o sistema judicial de reunião das duas modalidades de controle foi mantido. Entretanto, o constituinte não apenas manteve por completo o sistema da Constituição de 1967 e da Emenda de 1969; ele fez algumas mudanças, desconstruindo o isolamento entre os modelos concreto-difuso e abstrato-concentrado e desenvolvendo ainda mais o controle abstrato.

O constituinte de 1988 aprimorou o controle abstrato de normas. Uma das inovações implementadas foi a ampliação do rol dos legitimados para propor ação direta de inconstitucionalidade, rompendo o monopólio do Procurador-Geral da República, que já era objeto de profundas discussões doutrinárias e jurisprudenciais a respeito da sua obrigatoriedade de propor a ação ${ }^{36}$.

Outra mudança significativa em relação ao controle abstrato realizada pelo constituinte originário de 1988 está relacionada à omissão do legislador. Com relação a isso, o constituinte originário teve especial preocupação, criando a Ação Direta de Inconstitucionalidade por Omissão (art. $103, \S 2^{\circ}$ ) e o Mandado de Injunção (art. $5^{\circ}$, LXXI). Essa última ação é o instrumento disponível para resguardar direitos subjetivos que possam ser afetados negativamente pela omissão do legislador. Trata-se de ação constitucional de controle concreto-concentrado (art. 102, I, q), sendo, um exemplo do modelo complexo de controle de constitucionalidade judicial,

\footnotetext{
${ }^{36}$ Muito se discutiu a respeito da possível discricionariedade do Procurador-Geral para exercer o direito de Ação Direta de Inconstitucionalidade. Nomes como Pontes de Miranda e Caio Mario da Silva Pereira defendiam a obrigatoriedade do Procurador-Geral da República de propor a ação, impedindo que o PGR figurasse como juiz de constitucionalidade de uma norma. Por outro lado, doutrinadores de mesma importância, como José Carlos Barbosa Moreira e Raimundo Faoro, defendiam a discricionariedade do Procurador-Geral para propor a ação.
} 
pois reúne os modelos concreto-difuso e abstrato-concentrado. Já a ADIO é o instrumento de controle abstrato da omissão do legislador (art. 103, $\S 2^{\circ}$ ).

Além desses instrumentos, a Constituição de 1988 criou a Arguição de Descumprimento de Preceito Fundamental (art. 102, $\S 1^{\circ}$ ). Essa ação, que só veio a ser regulada pela Lei 9.882/99, tem como objetivo evitar ou reparar lesão a preceito fundamental ocasionada por ato do Poder Público, inclusive os atos anteriores à Constituição.

No âmbito estadual, a Carta Magna de 1988 criou a Representação de Inconstitucionalidade (art. 125, $\$ 2^{\circ}$ ). Esse instrumento é o meio adequado para o controle de constitucionalidade dentro do âmbito estadual, devendo, portanto, ser julgado pelo Tribunal de Justiça do Estado.

O texto constitucional originário de 1988 manteve o instituto da intervenção federal (art. 34, VII). A intervenção federal nos moldes desse dispositivo depende de provimento do STF, mediante representação do Procurador-Geral (art. 36, III).

Uma inovação importante relativa ao controle abstrato que não estava no texto constitucional originário de 1988 foi acrescentada pela Emenda Constitucional n. 3, de 1993. Trata-se da Ação Declaratória de Constitucionalidade. Essa ação está inserida no controle abstratoconcentrado, sendo competência do Supremo julgá-la. A regulamentação para o processo e julgamento dessa ação, bem como da ADI, foi estabelecida pela Lei n. 9.868/99.

Com essas inovações da Constituição de 1988, é possível notar que o controle abstrato de normas passou a ter ampla relevância. Isso, entretanto, não implica na desconstituição do controle concreto.

\subsection{Controle por via incidental ou concreto}

O controle difuso de constitucionalidade foi instituído no ordenamento jurídico brasileiro pela primeira vez pelo Decreto n. 848/1890 e foi consolidado pela primeira Constituição republicana brasileira. Até a 
Constituição de 1988, é possível considerar que essa modalidade de controle predominava no sistema brasileiro. Entretanto, o legislador constituinte originário de 1988 enfatizou o controle concentrado, passando a permitir o acesso direto ao Supremo para quase todas as questões constitucionais, como foi demonstrado no subcapítulo anterior ao se tratar do controle de constitucionalidade na Constituição de 1988. Apesar do fortalecimento do controle abstrato, o controle por via incidental continua sendo a única forma de qualquer cidadão buscar a tutela jurisdicional de seus direitos subjetivos constitucionais.

É dentro desse novo cenário que o controle incidental merece ser revisitado, pois esse modelo de controle judicial não sofreu substanciais alterações no desenvolvimento histórico do Direito brasileiro; agora, com uma atenção expressiva do legislador voltada ao controle abstratoconcentrado, é preciso dissecar o inabalável controle concreto.

Com relação ao modelo de controle concreto no direito brasileiro, é importante lembrar alguns pontos levantados anteriormente (Capítulo 3. 4. 1): a Constituição de 1934 atribuiu a competência ao Senado Federal para suspender a execução de quaisquer atos ou normas declaradas inconstitucionais pelo Supremo; e essa mesma Constituição inovou ao instituir como requisito para a declaração de inconstitucionalidade por um Tribunal a maioria absoluta dos votos. Esses aspectos do controle concreto estão presentes no texto constitucional de 1988 (art. 52, X e art. 97, respectivamente).

No controle concreto de constitucionalidade, a ação não tem como objeto a declaração de inconstitucionalidade de uma norma. A inconstitucionalidade deve ser invocada apenas como fundamento de argumentação. Portanto, no controle incidental, a dúvida sobre a constitucionalidade de uma norma surge ao se apreciar um conflito concreto submetido ao Poder Judiciário.

O controle de constitucionalidade por via incidental era, originalmente, reconhecido apenas à parte ré. Atualmente, porém, os outros 
entes do processo podem arguir o incidente de inconstitucionalidade. Assim, a inconstitucionalidade da norma além de poder ser suscitada pelas partes, pode ser arguida pelo próprio magistrado, pelo Ministério Público ou por terceiros que intervenham no processo.

Em relação ao objeto do controle incidental, é fundamental perceber que ele não encontra restrições como ocorre com o controle por via de ação. Desta maneira, pelo controle difuso, o órgão judicial, independentemente de ser estadual ou federal, pode declarar como inconstitucional lei federal, estadual ou municipal; também pode ser objeto dessa modalidade de controle os atos normativos secundários, como regulamentos, portarias e resoluções; e ainda, essa modalidade de controle pode ser exercida em relação às Constituições anteriores.

Por fazer parte da função jurisdicional comum do magistrado, o controle por via incidental pode ser exercido por qualquer juiz ou tribunal, configurando, assim, um controle difuso.

Quando o incidente de inconstitucionalidade for suscitado em um tribunal, o relator deve ouvir o Ministério Público e as partes e depois enviar o processo à Câmara ou à Turma competente (art. 948, CPC). O órgão fracionário pode rejeitar ou acolher a arguição. Se entender pela rejeição, o processo deve seguir normalmente, podendo a norma questionada ser aplicada; se, por outro lado, a arguição for acolhida, o que pode ocorrer por maioria simples, deve ser lavrado acórdão e a questão precisa ser levada ao plenário do tribunal ou ao seu órgão especial, se for o caso (art. 949, CPC).

O encaminhamento da questão constitucional ao plenário ou ao órgão especial é denominado cisão funcional de competência (art. 97, CF). Por essa cisão, cabe ao plenário ou ao órgão especial decidir somente sobre aquilo enviado pelo órgão fracionário. $\mathrm{O}$ incidente de inconstitucionalidade só será acolhido se houver maioria absoluta dos votos nesse sentido. A decisão do caso concreto cabe ao órgão fracionário, estando ele vinculado ao que foi decidido pelo plenário ou órgão especial. 
O parágrafo único do art. 949 do $\mathrm{CPC}$ estabelece uma excepcionalidade quanto à cláusula de reserva de plenário. Esse dispositivo estipula que os órgãos fracionários não devem submeter ao plenário ou órgão especial questão constitucional já decidida por estes ou pelo pleno do Supremo. Segundo Gilmar Mendes, essa previsão indica, ainda que timidamente, uma:

"equiparação entre efeitos da declaração de inconstitucionalidade em sede de
controle incidental com efeitos da declaração em controle concentrado. Decide-se
autonomamente com fundamento na declaração de inconstitucionalidade (ou de
constitucionalidade) do Supremo Tribunal Federal proferida incidenter tantum" ".

O art. 950 do Código de Processo Civil regula a participação de terceiros nos processos incidente de inconstitucionalidade. Segundo esse dispositivo, as pessoas jurídicas de direito público autoras do ato que tem a sua legitimidade constitucional questionada podem se manifestar mediante requerimento. Além dos autores do ato questionado, podem se manifestar também os legitimados previstos pelo art. 103 da Constituição. O legislador possibilita ainda ao relator admitir a participação de outras personagens, dependendo da matéria.

Esse dispositivo que trata da participação de amicus curiae no processo de decisão sobre o incidente de inconstitucionalidade, segundo Gilmar Mendes, gera "a efetiva abertura do processo de controle de constitucionalidade incidental, que passa, nesse ponto, a ter estrutura semelhante à dos processos de índole estritamente objetiva (ADI, ADC, ADPF)"38.

Visto como se processa o incidente de inconstitucionalidade perante juízes e tribunais, cumpre analisar como essa modalidade de controle é desempenhada pelo órgão de cúpula do Poder Judiciário brasileiro.

\footnotetext{
${ }^{37}$ MENDES, Gilmar Ferreira; BRANCO, Paulo Gustavo Gonet. Curso de Direito Constitucional. $8^{\mathrm{a}}$ ed. São Paulo: Saraiva, 2013. p. 1.072.

${ }^{38}$ Ibid., p. 1.074
} 


\subsubsection{Controle difuso no Supremo}

O Supremo também exerce controle de constitucionalidade incidental e pode fazê-lo tanto nas ações de competência originária como naquelas que devem ser analisadas pela Corte por via recursal (recursos ordinário ou extraordinário).

Assim, os arts. 169 a 178 do Regimento Interno do Supremo Tribunal Federal disciplinam como deve ocorrer o processamento e o julgamento, na mais alta Corte do país, das causas que envolvam questionamento acerca da constitucionalidade de uma norma.

Segundo o $\S^{\circ}$ do art. 176 do RISTF, a arguição de inconstitucionalidade feita em processo de competência de uma das Turmas do Supremo ocasiona o envio do feito ao Plenário do Tribunal, se considerada relevante. $\mathrm{O}$ mesmo deve ocorrer se se tratar de processo de competência do Presidente da Corte ou de competência dos Presidentes das Turmas (art. 176, $\S 2^{\circ}$, RISTF). Ao Plenário caberá julgar a prejudicial de inconstitucionalidade, bem como o restante da causa (art. 177, RISTF).

O art. 143 do RISTF estabelece o quórum mínimo de seis Ministros para o Plenário se reunir. Todavia, ao se tratar de matéria constitucional, o quórum exigido passa a ser de oito Ministros, conforme o parágrafo único do artigo supra citado. Ademais, a inconstitucionalidade somente será declarada se seis Ministros se manifestarem neste sentido (art. 173, RISTF).

Se a inconstitucionalidade for reconhecida pelo Plenário, o órgão responsável pela edição daquela norma deve ser comunicado logo após a decisão. Já o Senado Federal também deve ser comunicado, porém, após o trânsito em julgado (art. 178, RISTF). A comunicação ao Senado deve ser feita em razão do art. 52, X da Constituição Federal. A Alta Casa Legislativa poderá, então, suspender a execução da norma declarada inconstitucional pelo STF.

Ao se tratar das competências do Supremo Tribunal Federal (Capítulo 2. 2. 2. 1), foi dito que, conforme o art. 102 da Constituição, o 
Tribunal possui competências originárias e também pode ser provocado via recurso, podendo ser ordinário ou extraordinário.

Dentre essas competências do STF está o julgamento de recursos extraordinários relativos ao controle de constitucionalidade incidental das normas (art. 102, III, b e c). Assim, dispõe a Constituição que cabe ao Supremo julgar recursos extraordinários interpostos contra decisões de última ou única instância que: declararem a inconstitucionalidade de tratado ou lei federal ou julgarem válida lei ou ato de governo local contestado em face da Constituição.

O presente trabalho, ao tratar de recursos extraordinários (Capítulo 2. 2. 2. 1. 1), fez alusão à repercussão geral, que está prevista no $\S 3^{\circ}$, do art. 103 da Constituição. Esse instituto demonstra uma objetivação do processo, isto é, desenvolve-se um novo paradigma de que as causas julgadas em recurso extraordinário pelo STF deixam de se relacionar apenas com os interesses subjetivos das partes envolvidas, refletindo em outras demandas.

Outras medidas neste mesmo sentido já foram instituídas no ordenamento e levantadas neste trabalho, tais como: a manifestação de amicus curiae, nos termos do art. 950, do CPC, possibilitando a participação de terceiros nos processos de controle de constitucionalidade incidental (Capítulo 3. 5); o posicionamento do STF no RE 102.553/RJ ${ }^{39}$ para analisar a constitucionalidade de outras normas, mesmo não sendo do interesse das partes (Capítulo 2. 2. 2. 1. 1); e no julgamento da ADI 4.071/ $\mathrm{DF}^{40}$, no qual o Supremo entendeu que deve ser julgada improcedente a ação direta de inconstitucionalidade que questionar a mesma norma que teve sua constitucionalidade reconhecida em julgamento de recurso extraordinário anterior (Capítulo 2. 2. 2. 1. 1).

Além dessas demonstrações de objetivação dos processos de controle de constitucionalidade incidental, produzindo efeitos para além das partes

\footnotetext{
${ }^{39}$ STF, RE n. 102.553/RJ, Rel. Min. Francisco Rezek, Brasília, 13 fev. 1987.

${ }^{40}$ STF, ADI n. 4.071/DF, Rel. Min. Menezes Direito, Brasília, 22 out. 2009.
} 
envolvidas naquele processo - regra diferente daquela do art. 506 do CPC -, é possível mencionar outras decisões do Supremo neste mesmo sentido:

1 - O MS 20.505/DF ${ }^{41}$ foi interposto contra ato do Presidente da República que designava temporariamente prefeito para a cidade de Osório. O Ministro Relator votou no sentido de que era desnecessário avaliar a constitucionalidade do ato presidencial questionado frente ao Supremo, uma vez que se verificava a ilegalidade do ato. Entretanto, o Tribunal, pela característica de sua função de guardião da Constituição, não acompanhou o posicionamento do Relator e garantiu o direito líquido e certo da parte autora, reconhecendo a inconstitucionalidade do ato da autoridade coatora.

2 - Ao decidir a Sentença Estrangeira 5.206/Espanha ${ }^{42}$, o Supremo, utilizando o entendimento firmado no mandado de segurança citado acima (deve se manifestar, pois é guardião da Constituição), analisou incidentalmente a constitucionalidade de dispositivos da Lei de Arbitragem (Lei n. 9.307/96), mesmo não sendo fundamental para a decisão sobre a homologação da sentença estrangeira. Nesse julgamento, o Supremo entendeu que deveria analisar diversos tópicos da Lei de Arbitragem, principalmente a compatibilidade entre a cláusula compromissória e o princípio da universalidade da jurisdição do Poder Judiciário (art. $5^{\circ}, \mathrm{XXXV}, \mathrm{CF}$ ).

3 - A Ação Originária 499/DF ${ }^{43}$ foi impetrada por Ministro do Superior Tribunal Militar que pleiteava a concessão de auxílio-alimentação, com base no Ato n. 274 do STM, que havia concedido esse direito ao Juízes Auditores da Justiça Militar da União. Ao julgar a ação, o Supremo entendeu que o Ato do STM que concedia auxílio-alimentação era inconstitucional, pois esse auxílio não estava presente no art. 65, $\S 2^{\circ}$ da Lei Orgânica da Magistratura Nacional (Lei Complementar n. 35/79).

Todas essas medidas mencionadas direcionam o controle incidental das normas no caminho da objetivação do processo, deixando o âmbito da relação entre as partes. Assim, as decisões do Supremo em controle de constitucionalidade concreto afastam-se do processo subjetivo comum, e,

\footnotetext{
${ }^{41}$ STF, MS n. 20.505/DF, Rel. Min. Néri da Silveira, Brasília, 8 nov. 1991.

${ }^{42}$ STF, SE n. 5.206/EP, Rel. Min. Sepúlveda Pertence, Brasília, 30 abr. 2004.

${ }^{43}$ STF, AO 499/DF, Rel. Min. Maurício Corrêa, Brasília, 1ª ago. 2003.
} 
em razão disso, acabam por refletir em outros processos. Para compreender plenamente essa alteração, é preciso analisar como se produzem os efeitos das decisões do STF em controle incidental.

\subsubsection{Efeitos da decisão do Supremo e 0 artigo $52, X$ da Constituição}

O limite subjetivo dos efeitos de uma decisão judicial é estabelecido pelo art. 506 do Código de Processo Civil, que estipula que a coisa julgada está limitada às partes do processo. Já o limite objetivo da coisa julgada é estabelecido pelos arts. 503 e 504 do CPC. O primeiro deles restringe a coisa julgada à questão principal expressamente decidida; enquanto o art. 504, por meio de seu inciso I, estipula que os motivos da decisão não constituem coisa julgada.

Assim, dentro do processo em que se aprecia a validade constitucional de uma norma, a decisão do juízo produz efeitos inter partes e, como a inconstitucionalidade da norma não é pedido do autor ou do réu, mas sim fundamento do pedido de um deles, não há como ela constituir coisa julgada.

Em relação à eficácia temporal da decisão, é fundamental lembrar que o Direito brasileiro adota amplamente a corrente de que a lei inconstitucional é nula. Assim, essa lei não deve ser capaz de produzir efeitos. Portanto, no controle de constitucionalidade incidental, a decisão do juiz que reconhece a inconstitucionalidade deve produzir efeitos retroativos, impossibilitando uma norma inconstitucional de gerar direitos e obrigações. É possível, entretanto, admitir algumas exceções a essa regra geral, como prevê a Lei que regulamenta as Ações Diretas (Lei 9.868/99), em seu art. 27. Além da modulação de efeitos nos casos de Ação Direta, o Supremo admite a modulação de efeitos no controle incidental. Cabe ressaltar que a teoria da nulidade da norma inconstitucional constitui entendimento majoritário da doutrina, mas não unânime. 
O STF exerce controle de constitucionalidade incidental em processos de sua competência originária e de sua competência recursal. Esse modelo tem um detalhe singular que difere profundamente uma decisão do Supremo em controle de constitucionalidade de uma decisão de qualquer outro tribunal. Trata-se de comunicação da decisão que reconhece a inconstitucionalidade da norma ao Senado Federal (art. 52, X).

Segundo Luís Roberto Barroso, a instituição dessa competência ao Senado Federal tem uma razão identificável:

\begin{abstract}
"A razão histórica - e técnica - da intervenção do Senado é singelamente identificável. No direito norte-americano, de onde se transplantara o modelo de controle incidental e difuso, as decisões dos tribunais são vinculantes para os demais órgãos judiciais sujeitos à sua competência revisional. Isso é válido inclusive, e especialmente, para os julgados da Suprema Corte. Desse modo, o juízo de inconstitucionalidade por ela formulado, embora relativo a um caso concreto, produz efeitos gerais. Não assim, porém, no caso brasileiro, onde a tradição romano-germânica vigorante não atribui eficácia vinculante às decisões judiciais, nem mesmo às do Supremo Tribunal. Desse modo, a outorga ao Senado Federal de competência para suspender a execução da lei inconstitucional teve por motivação atribuir eficácia geral, em face de todos, erga omnes, à decisão proferida no caso concreto, cujos efeitos se irradiam, ordinariamente, apenas em relação às partes do processo" 4 .
\end{abstract}

Assim, o Brasil havia incorporado, pela Constituição de 1891, o controle de constitucionalidade americano. Entretanto, não incorporou a doutrina do stare decisis, e, portanto, as decisões do Supremo tinham seus efeitos restritos às partes do processo. Para aperfeiçoar o modelo de controle brasileiro, o legislador de 1934 introduziu a competência do Senado a fim de, por meio de resolução, suspender a execução de norma declarada inconstitucional pelo Supremo.

A concessão dessa competência ao Senado está intimamente conectada com a função que a Constituição de 1934 atribuiu a essa Casa Legislativa. $\mathrm{O}$ art. 22 dessa Constituição estabelecia que o Poder Legislativo seria exercido pela Câmara dos Deputados, com o Senado Federal atuando como colaborador; e o art. 88 atribuía ao Senado o papel de

\footnotetext{
${ }^{44}$ BARROSO, Luís Roberto. O Controle de Constitucionalidade no Direito Brasileiro: exposição sistemática da doutrina e análise crítica da jurisprudência. $7^{\text {a }}$ ed. São Paulo: Saraiva, 2015. p. 166.
} 
coordenador entre os poderes. Assim, é importante realçar que as competências atribuídas ao Senado não estavam inseridas nas competências do Poder Legislativo (arts. 22 a 50), mas sim no Capítulo V, destinado à "Coordenação entre os Poderes" (arts. 88 a 94).

Portanto, quando a Constituição de 1934 atribui competência ao Senado Federal de suspender a execução de qualquer lei declarada inconstitucional pelo Poder Judiciário (art. 91, IV), o faz em consonância com o papel atribuído a esse órgão, já que era o responsável pela coordenação entre os Poderes. Por isso, é possível entender que essa atribuição não estabelecia conflito com o princípio da separação dos poderes ou com o controle de constitucionalidade.

A suspensão da norma inconstitucional pelo Senado é solução singular para atribuir eficácia geral às decisões do Supremo no controle de constitucionalidade difuso. Por isso, acaba resultando em controvérsias de difícil resolução. Dentre as questões que surgem a partir dessa previsão constitucional, destacam-se duas aqui: os efeitos e a natureza da resolução editada pelo Senado; e a discricionariedade, ou a ausência dela, para a edição do ato.

Em relação à segunda questão (discricionariedade ou não do Senado), houve considerável desacordo doutrinário. Parte da doutrina entendia que a suspensão da norma inconstitucional pelo Senado era um ato político, discricionário. Nesse sentido, é possível citar lição de Paulo Napoleão Nogueira da Silva:

“[...] o ato de suspender a execução de um diploma legal é eminentemente político, e, portanto, de conveniência. Tanto assim que, nenhuma sanção ou consequência positiva de qualquer natureza se conhece, para o caso de tal ato deixar de ser praticado" 45 .

Assim, quando o autor analisa a suspensão pelo Senado na Carta de 1967 conclui que:

\footnotetext{
${ }^{45}$ SILVA, Paulo Napoleão Nogueira da. A evolução do Controle da Constitucionalidade e a competência do Senado Federal. São Paulo: Revista dos Tribunais, 1992. p. 74.
} 
"a disposição [...] se faz sem a interferência ou participação de qualquer outro órgão, e, no entanto, a atuação do Supremo Tribunal Federal estava expressamente mencionada no próprio corpo do inc. VII do art. 42, tudo leva a crer, sempre neste primeiro exame, que essa atuação do Supremo não vinculava: antes, era uma espécie de requisito para o exercício da competência constitucional atribuída privativa e livremente ao Senado" ${ }^{46}$.

Além do autor supramencionado, é possível citar outros ilustres doutrinadores: Paulo Brossard ${ }^{47}$ e Alfredo Buzaid ${ }^{48}$. Ambos os autores, assim como Paulo Napoleão Nogueira, defenderam o entendimento de que a suspensão da execução de norma inconstitucional era ato político, discricionário.

A outra parte da doutrina defende que a suspensão pelo Senado da norma declarada inconstitucional pelo Supremo devia ser entendida como ato vinculado, e não político. Neste sentido, cita-se juízo de Miguel Seabra Fagundes:

\begin{abstract}
"Pretender que o Senado recuse suspender a execução da lei, caso o Supremo lhe faça, para tanto, a necessária comunicação, atribuindo, a essa atitude, a força de convalidar o texto declarado inconstitucional, ou, pelo menos, de desprestigiar o pronunciamento de inconstitucionalidade, se nos afigura absolutamente indefensável. Juridicamente e politicamente. Juridicamente porque no sistema da nossa Constituição, o Supremo é o árbitro final da constitucionalidade das leis, não cabendo ao Senado, nem de longe, rever os seus critérios. Se o admitíssemos estaríamos tornando ao malsinado e infelicíssimo sistema do artigo 96, da Carta de 1937, segundo o qual o contencioso de constitucionalidade das leis tinha a sua palavra final, não no juízo jurídico dos tribunais, porém no critério político do Parlamento" 49 .
\end{abstract}

Além de Seabra Fagundes, Lucio Bittencourt se pronunciou no sentido de que as decisões do Supremo não precisariam da autorização do Senado Federal para produzir todos os seus efeitos. A resolução do Senado se prestaria apenas a dar publicidade à decisão da Corte. Nesse sentido:

\footnotetext{
${ }^{46}$ Ibid., p. 75

47 Cf. BROSSARD, Paulo. O Senado e as leis inconstitucionais. Disponível em < http://www2.senado.leg.br/bdsf/bitstream/handle/id/181304/000393215.pdf?sequence=3>. Acesso em 20 abr. 2017.

${ }^{48}$ Cf. BUZAID, Alfredo. Da ação direta de declaração de inconstitucionalidade no direito brasileiro. São Paulo: Saraiva, 1958.

49 Revista de Informação Legislativa, ano III, n. 9. p. 201. Disponível em < http://www2.senado.leg.br/bdsf/handle/id/496744>. Acesso em 10 mai. 2017.
} 
"Se o Senado não agir, nem por isso ficará afetada a eficácia da decisão, a qual continuará a produzir todos os seus efeitos regulares que, de fato, independem de qualquer dos poderes. O objetivo do art. 45 , IV da Constituição é apenas tornar pública a decisão do tribunal, levando-a ao conhecimento de todos os cidadãos. Dizer que o Senado 'suspende a execução' da lei inconstitucional é, positivamente, impropriedade técnica, uma vez que o ato, sendo 'inexistente' ou 'ineficaz', não pode ter suspensa a sua execução"s0

A outra questão oriunda da suspensão de norma pelo Senado está relacionada aos efeitos e à natureza da resolução da Casa Legislativa. Em outras palavras, não há entendimento unânime na doutrina se a manifestação do Senado gera efeitos ex tunc ou ex nunc.

Essa discussão decorre da falta de clareza na redação do art. 52, X da Constituição, isto é, o legislador - desde 1934 - não se preocupou em esclarecer se a resolução do Senado geraria efeitos retroativos ou não.

A doutrina majoritária - e que foi exposta no presente trabalho (Capítulo 3. 1. 1) - segue a linha de que a decisão que reconhece a inconstitucionalidade de uma norma opera efeitos ex tunc, tendo caráter apenas declaratório. Dessa maneira, por a inconstitucionalidade se manifestar no plano da validade, é inconcebível que atos praticados com base numa norma inconstitucional sejam entendidos como juridicamente perfeitos ou gerem direitos adquiridos.

Essa teoria, aparentemente, também foi adotada pelo legislador, ao promulgar o Decreto n. 2.346/97, que trata de procedimentos a serem observados pela Administração Pública Federal em razão de decisões judiciais. Os $\S \S 1^{\circ}$ e $2^{\circ}$ do art. $1^{\circ}$ do Decreto determinam que as decisões do Supremo em ação direta são dotadas de eficácia ex tunc. No mesmo sentido, refere-se à decisão do Supremo em controle incidental, após manifestação do Senado.

Esse entendimento é majoritário, mas não unânime. Notáveis são os autores que defendem que a resolução do Senado produziria efeitos apenas

\footnotetext{
${ }^{50}$ BITTENCOURT, Carlos Alberto Lucio. O controle jurisdicional da constitucionalidade das leis. $2^{\mathrm{a}}$ ed. Rio de Janeiro: Forense, 1968. p. 145-146.
} 
a partir de sua efetivação, sem atingir negócios jurídicos celebrados com base na lei inconstitucional. Nessa corrente, estão nomes como Temístocles Cavalcanti $^{51}$ e Oswaldo Aranha Bandeira de Mello ${ }^{52}$.

Contudo, essa visão minoritária parece confundir a suspensão de uma norma com a sua revogação. Esses institutos podem ser assim distinguidos, segundo Teori Zavascki:

\begin{abstract}
"A norma revogada deixa de incidir a partir de sua revogação, mas incidiu validamente sobre os suportes fáticos ocorridos durante a sua vigência. Isso significa que, mesmo depois da sua revogação, a norma pode e deve ser aplicada pelo juiz, pelo administrador público e por quem mais tenha de apreciar controvérsias sobre os fatos jurídicos anteriores. No caso de suspensão por inconstitucionalidade, as consequências são diferentes. A norma inconstitucional é nula desde a origem, e, como tal, nunca teve aptidão para operar o fenômeno da incidência. É norma que nunca incidiu" ${ }^{\prime 53}$.
\end{abstract}

Ademais, Temístocles Cavalcanti justifica sua posição de que a resolução opera efeitos ex nunc por entender que essa seria a melhor maneira de atender à “ordem pública”. Entretanto, a legislação (art. 27, Lei n. 9.868/99) e o Supremo já admitem que, em razão de segurança jurídica ou de excepcional interesse social, é possível pode modular os efeitos da declaração de inconstitucionalidade, inclusive nos casos de controle incidental, fazendo com que suas decisões operem efeitos a partir de determinado momento.

Antes da promulgação da Constituição de 1988, o Supremo teve oportunidade de se manifestar sobre essas duas polêmicas (se a suspensão pelo Senado seria ato vinculado; e se a resolução produziria efeitos daquele momento em diante, ou se retroagiria). Tal ocasião ocorreu pelo julgamento do MS $16.512^{54}$, o qual foi impetrado contra o Senado Federal em razão de essa Casa Legislativa ter editado uma resolução (n. 93, de 14-10-1965)

\footnotetext{
${ }^{51}$ Cf. CAVALCANTI, Themístocles Brandão. Do controle de constitucionalidade. Rio de Janeiro: Forense, 1966.

${ }^{52}$ Cf. MELLO, Oswaldo Aranha Bandeira de. Teoria das constituições rígidas. $2^{\mathrm{a}}$ ed. São Paulo: José Bushatsky, 1980.

${ }^{53}$ ZAVASCKI, Teori. Eficácia das sentenças na jurisdição constitucional. p. 31. Disponível em < https://www.lume.ufrgs.br/bitstream/handle/10183/2521/000275909.pdf?sequence=1>. Acesso em 2 maio 2017.

${ }^{54}$ STF, MS n. 16.512/DF, Rel. Min. Oswaldo Trigueiro, Brasília, 31 ago. 1966.
} 
revogando resolução anterior (n. 32, de 25-3-1965), ambas dispunham sobre a suspensão de norma declarada inconstitucional pelo Supremo. Nessa oportunidade, o STF se manifestou no sentido de que não recaía sobre o Senado qualquer obrigação para suspender norma declarada inconstitucional, recepcionando, assim, a teoria de que a suspensão era ato discricionário ${ }^{55}$.

Ao julgar esse Mandado de Segurança, entendeu o Supremo que o Senado não poderia revogar sua resolução anterior. Além disso, o STF considerou que a competência do Senado determinada pelo art. 64 da Constituição de 1946 “estava vinculada à extensão do julgado do Supremo Tribunal"56, uma vez que a Alta Casa do Congresso não era competente para suspender a vigência de qualquer lei, apenas daquelas declaradas inconstitucionais pelo STF.

Portanto, ao julgar o MS 16.512, o Supremo se posicionou no sentido de que a manifestação do Senado concederia efeito amplo à decisão do Supremo, que tinha eficácia apenas entre as partes do processo. Todavia, o Senado não estava obrigado a se manifestar, mas se o fizesse estaria vinculado à decisão do STF, não podendo restringi-la ou ampliá-la.

A decisão tomada pelo Supremo no Mandado de Segurança citado anteriormente fixou a posição da Corte quanto à manifestação do Senado no processo de controle de constitucionalidade incidental. Esse processo foi julgado em 1966, ou seja, antes da promulgação da Constituição Cidadã. Com as mudanças introduzidas pela Constituição de 1988, e com todas as alterações posteriores promovidas no sistema de controle de constitucionalidade, parte da doutrina indica que deve haver um novo entendimento da norma do art. 52, $\mathrm{X}$, diferente daquele estabelecido pelo Supremo em 1966.

\footnotetext{
${ }^{55}$ Nesse sentido, ao manifestar seu voto no MS n. 16.512/DF, o Ministro Victor Nunes Leal defende: "O Senado não é um autômato na aplicação do art. 64. O Senado pode, a meu ver, julgar da oportunidade de suspender ou não a execução de lei que tenhamos declarado inconstitucional. E, há de levar em conta, em tais circunstâncias, a possível oscilação da jurisprudência do Tribunal $(\ldots)$ ".

${ }^{56}$ STF, MS n. 16.512/DF, Rel. Min. Oswaldo Trigueiro, Brasília, 31 ago. 1966. Voto do Ministro Victor Nunes Leal.
} 
A oportunidade para o Supremo fixar um novo entendimento, superando aquele construído em 1966, veio com o julgamento da Reclamação n. 4.335/AC ${ }^{57}$, que será objeto de análise do próximo capítulo. 


\section{A Reclamação 4.335/AC: uma nova manifestação do Supremo sobre 0 artigo 52, X da Constituição}

\subsection{Resumo do caso}

O Supremo Tribunal teve nova oportunidade de se manifestar sobre o papel do Senado no controle de constitucionalidade difuso. Tal ocasião surgiu quando a Defensoria Pública da União ajuizou reclamação constitucional contra decisão do Juiz de Direito da Vara de Execuções Penais da Comarca de Rio Branco (Acre), a qual indeferiu os pedidos de progressão de regime para condenados por crimes hediondos ou a eles equiparados.

Para a compreensão do caso, é preciso destacar em quais situações uma Reclamação pode ser ajuizada. Com efeito, a Constituição, por meio do art. 102, I, 1, estabelece que uma Reclamação para o STF pode ser ajuizada para preservação de sua competência ou para garantir a autoridade de suas decisões. Além disso, a Emenda Constitucional n. 45/2004 introduziu o art. 103-A, o qual, por meio de seu $\S 3^{\circ}$, indica a Reclamação como instrumento adequado para contestar ato administrativo ou decisão judicial contrários à Súmula Vinculante.

Dessa maneira, a DPU alegou que o reclamado havia descumprido a decisão do Supremo tomada no julgamento do HC 82.95958. Ao julgar esse habeas corpus, o STF reconheceu a inconstitucionalidade da vedação de progressão de regime nos casos de crimes hediondos ou a eles equiparados (art. $2^{\circ}, \S 1^{\circ}$, Lei n. 8.072/1990). Segundo o entendimento do STF, a vedação conflitava com a garantia constitucional de individualização da pena (art. $5^{\circ}$, XLVI).

Tendo em vista esse julgado, a Defensoria Pública solicitou ao Juiz da Vara de Execuções Penais de Rio Branco a concessão de progressão de

\footnotetext{
${ }^{58}$ STF, HC n. 82.959/SP, Rel. Min. Marco Aurélio, Brasília, 23 fev. 2006.
} 
regime de alguns condenados por crimes hediondos ou a eles equiparados. O reclamado, porém, negou o pedido, por entender que a decisão do Supremo somente teria eficácia entre as partes do processo dentro do qual foi proferida, somente adquirindo eficácia geral com a suspensão da norma pelo Senado (art. 52, X da Constituição); e como não havia manifestação do Senado para a suspensão, o reclamado entendia que a norma ainda estaria em vigor.

Portanto, observa-se que o Juiz da Vara de Execuções Penais de Rio Branco deixou de aplicar o entendimento do Supremo quanto à inconstitucionalidade da vedação de progressão de regime de cumprimento de penas com base na doutrina clássica sobre o papel do Senado no controle de constitucionalidade difuso, exposta no capítulo anterior. Tal doutrina, como já demonstrado anteriormente, foi adotada pelo Supremo ao julgar o MS 16.512/DF ${ }^{59}$.

A Reclamação ajuizada pela Defensoria Pública da União continha pedido de decisão liminar. O Relator, Ministro Gilmar Mendes, atendeu a esse pedido da DPU, afastando a vedação da progressão de regime nos casos de crimes hediondos ou a eles equiparados.

Importante notar que, durante o tempo decorrido no julgamento da reclamação, o Supremo editou uma Súmula Vinculante, a de n. 26, consolidando o entendimento sobre a inconstitucionalidade da vedação de progressão de regime de cumprimento de pena para os condenados por crimes hediondos ou a eles equiparados. Essa súmula não existia quando a ação foi proposta e, com esse fundamento, alguns Ministros votaram pelo não conhecimento da ação.

Após a decisão do Ministro Gilmar Mendes em sede liminar, a Reclamação seguiu para análise do plenário da Corte. No plenário, o Relator proferiu um voto polêmico que indicava uma completa transformação do papel do Senado no controle difuso.

\footnotetext{
${ }^{59}$ STF, MS n. 16.512/DF, Rel. Min. Oswaldo Trigueiro, Brasília, 31 ago. 1966.
} 


\subsection{O voto do Ministro Gilmar Mendes}

A primeira questão que o Relator teve de analisar referia-se ao cabimento da Reclamação. Segundo os pareceres da Procuradoria-Geral da República e do Ministério Público, e ainda, segundo manifestação da autoridade reclamada, tratava-se de Reclamação incabível, pois não existiria decisão proferida pelo Supremo que devesse ser resguardada.

Para responder a essa questão, Gilmar Mendes analisou a eficácia da decisão proferida pelo STF no HC 82.959. Em outras palavras, o Ministro analisou se somente seria atribuída eficácia geral à decisão da Corte em controle difuso por manifestação do Senado.

Portanto, verifica-se que caberia ao Relator, ao proferir seu voto, analisar o papel desempenhado pelo Senado no controle de constitucionalidade judicial, tal como foi feito pelo Supremo ao julgar o MS 16.512, em 1966.

Em seu voto, o Ministro defendeu seu posicionamento de destaque em relação ao instituto de suspensão da lei inconstitucional pelo Senado, como já fazia em obras de sua autoria. Segundo ele, a norma do art. 52, X da Constituição "perdeu parte de seu significado com a ampliação do controle abstrato de norma, sofrendo mesmo um processo de obsolescência" ${ }^{60}$. Para complementar seu raciocínio questiona o Ministro:

\footnotetext{
"Se o Supremo Tribunal pode, em ação direta de inconstitucionalidade, suspender, liminarmente, a eficácia de uma lei, até mesmo de emenda constitucional, por que haveria a declaração de inconstitucionalidade, proferida no controle incidental, valer tão somente para as partes" ${ }^{\prime \prime 1}$.
}

Dessa forma, Gilmar Mendes defende a superação do entendimento clássico do art. 52, X da Constituição em razão de algumas transformações pelas quais o sistema de controle de constitucionalidade no Direito brasileiro passou.

\footnotetext{
${ }^{60}$ MENDES, Gilmar Ferreira; BRANCO, Paulo Gustavo Gonet. Curso de Direito Constitucional. $8^{\mathrm{a}}$ ed. São Paulo: Saraiva, 2013. p. 1.091.

${ }^{61}$ Ibid., 1.091
} 
A primeira dessas alterações é a preponderância que o controle abstrato de normas passou a ter em relação ao controle concreto com a Constituição de 1988. Com a nova Constituição, houve um destaque maior para o controle abstrato de normas, vindo, primeiramente, com a ampliação dos legitimados para propor a ação direta de inconstitucionalidade (art. 103); e, posteriormente, com a introdução da Ação Declaratória de Constitucionalidade. Além desses instrumentos, ainda foi instituída a Ação de Descumprimento de Preceito Fundamental (ADPF) para tratar dos casos que não poderiam ser objeto de ADI ou ADC.

Uma segunda alteração no sistema brasileiro que, segundo Gilmar Mendes, pode implicar em uma releitura do art. 52, X da Constituição é a introdução de novas legislações que prestigiam a jurisprudência do Supremo Tribunal Federal, ampliando os efeitos das decisões da Corte. Como exemplo, o Ministro cita a Lei n. 8.038/1990, que possibilita ao relator negar provimento ao recurso manifestamente intempestivo, incabível ou, improcedente ou ainda, que contrarie súmula do respectivo Tribunal ou do STF (art. 38).

Esse prestígio dado pelo legislador às decisões do Supremo também pode ser observado no parágrafo único do art. 949 do Código de Processo Civil. Esse dispositivo prevê que os órgãos fracionários não devem enviar arguição de inconstitucionalidade ao plenário ou ao órgão especial se já houver manifestação do Tribunal ou do Supremo sobre a questão.

Assim, o segundo ponto feito pelo Relator baseia-se na autoridade conferida pelo legislador às decisões da Suprema Corte. Dessa maneira, segundo ele, o próprio legislador deseja prestigiar as decisões do STF, não havendo razão para a subsistência do entendimento clássico do art. $52, \mathrm{X}$ da Constituição.

Além desses dois pontos, as ações coletivas também são apontadas como fundamento para a superação do entendimento clássico sobre a suspensão operada pelo Senado, pois, nessas ações, não há como atribuir 
eficácia inter partes às decisões, sendo a manifestação do Senado inútil. Nesse sentido, o art. 16 da Lei n. 7.347/85 prevê efeitos erga omnes.

É exatamente esse o entendimento que a jurisprudência resolveu adotar, conforme mostra o Relator ao destacar a ADI n. 1.91962. Essa Ação Direta de Inconstitucionalidade foi proposta contra o Provimento n. 556/97, elaborado pelo Conselho Superior da Magistratura do Estado de São Paulo. Esse provimento estabelecia a destruição física dos autos judiciais relativos a processos julgados e arquivados na primeira instância há mais de cinco anos. A ADI foi julgada prejudicada por já haver decisão do STJ em Mandado de Segurança Coletivo ${ }^{63}$ que havia declarado a nulidade daquela resolução.

De fato, as ações coletivas representam uma exceção ao entendimento clássico do art. 52, X da Constituição. Entretanto, o efeito geral das decisões em ações coletivas não implica necessariamente na superação do instrumento de suspensão da norma inconstitucional pelo Senado, pois o efeito erga omnes das decisões nas ações dessa natureza está ligado ao objeto das ações, e não com a suposta obsolescência do art. 52, X da Constituição.

O quarto ponto destacado por Gilmar Ferreira Mendes é a introdução das Súmulas Vinculantes no ordenamento jurídico brasileiro (art. 103-A da Constituição). A edição de uma Súmula Vinculante que tenha como objeto a inconstitucionalidade de uma norma, segundo o Relator, enfraquece o instituto da suspensão da execução da norma pelo Senado, pois a edição dessa Súmula pelo STF já concede efeito geral e vinculante à sua decisão, independentemente de manifestação por parte do Senado.

Uma Súmula Vinculante pode ter como objeto a inconstitucionalidade de uma norma, como o Supremo fez ao editar a Súmula Vinculante n. 26, a qual consolida o entendimento da Corte a respeito da inconstitucionalidade do art. $2^{\circ}$, $\S 1^{\circ}$, Lei n. 8.072/1990.

\footnotetext{
${ }^{62}$ STF, ADI n. 1.919/SP, Rel. Min. Ellen Gracie, Brasília, 1º ago. 2003.

${ }^{63}$ STJ, RMS n. 11.824/SP, Rel. Min. Francisco Peçanha Martins, Brasília, 27 mai. 2002.
} 
Entretanto, esse argumento não parece favorecer a tese do Ministro Relator, pois, embora as Súmulas Vinculantes apontem para um prestígio maior dos entendimentos do Supremo, os requisitos para sua edição são mais rigorosos do que aqueles necessários para a declaração de inconstitucionalidade de uma norma pelo Supremo em controle difuso. $\mathrm{Ou}$ seja, o legislador, ao instituir um instrumento como as Súmulas Vinculantes, aponta para uma valorização do entendimento da Suprema Corte, porém, ele estabelece requisitos (voto de dois terços dos Ministros e reiteradas decisões) mais rigorosos do que a maioria exigida no controle difuso para a declaração de inconstitucionalidade.

O último ponto destacado por Gilmar Mendes que, segundo ele, revela a necessidade de uma releitura da suspensão da norma inconstitucional pelo Senado, está relacionado à jurisprudência do Supremo Tribunal Federal nos casos de controle de constitucionalidade de normas municipais. Nesses casos, o STF tem se posicionado no sentido de estender os efeitos da decisão de um caso para outros casos idênticos. Ou seja, o Supremo, ao julgar como inconstitucional uma lei municipal, confere efeito vinculante aos fundamentos daquela decisão, sendo ela aplicável a outros municípios em situação idêntica, sem que haja, necessariamente, a manifestação do Senado.

Como exemplo desse último argumento, o Relator destaca o RE 228.844/SP ${ }^{64}$, no qual, por decisão monocrática, o relator deu provimento ao recurso extraordinário para julgar inconstitucional lei do Município de São José do Rio Preto que estabelecia a progressividade do IPTU levando em consideração a capacidade econômica do contribuinte. O relator decidiu dessa maneira em razão de pronunciamento anterior do plenário do STF neste sentido, ao julgar o RE 153.771/ $\mathrm{MG}^{65}$, que tratava da progressividade do IPTU, considerando a capacidade contributiva do sujeito passivo da relação tributária, estabelecida por lei do Município de Belo Horizonte.

\footnotetext{
${ }^{64}$ STF, RE n. 228.844/SP, Rel. Min. Maurício Corrêa, Brasília, 16 jun. 2009.

${ }^{65}$ STF, RE n. 153.771/MG, Rel. Min. Moreira Alves, Brasília, 5 set. 1997.
} 
Outra matéria destacada pelo Ministro Relator diz respeito à taxa de iluminação pública. Assim, a Min. Ellen Gracie, ao julgar o RE 364.160/MG $\mathrm{MG}^{66}$, decidiu, de maneira monocrática, que a taxa de iluminação pública instituída pelo Município de Cabo Verde era inconstitucional. Em sua decisão, a Ministra citou o julgamento do RE 233.332/RJ ${ }^{67}$, no qual o plenário do Supremo havia decidido pela inconstitucionalidade de Lei do Município de Niterói que instituía a taxa de iluminação pública.

Essas são apenas algumas das várias decisões em que há a dispensa de manifestação do plenário do Supremo para avaliar casos idênticos a outros já julgados. Ou seja, o Ministro Relator, analisando caso idêntico a outro já julgado pelo plenário da Corte, pode aplicar essa decisão anterior e decidir a matéria monocraticamente, se se tratar de casos idênticos. Assim, é possível entender, segundo Gilmar Ferreira Mendes, que há um efeito vinculante dos fundamentos utilizados pelo plenário do Supremo no controle de constitucionalidade de lei municipal.

Ao adentrar na conclusão de seu voto, o Ministro Relator demonstra o entendimento de que a jurisprudência e a legislação têm se posicionado no sentido de esvaziar o modelo de suspensão de execução da norma pelo Senado. Em outras palavras, as mudanças citadas acima deveriam alterar a leitura clássica do art. 52, X da Constituição.

Dessa maneira, para Gilmar Mendes, o posicionamento do legislador e do próprio Supremo demonstram que as decisões da Corte são dotadas de "efeito transcendente", ainda que sem a manifestação do Senado, nos termos do art. 52, X da Constituição. Ou seja, em razão da reformulação que o sistema de controle de constitucionalidade das normas sofre, com destaque para a primazia do controle abstrato em relação ao controle difuso, para o Relator, é possível identificar verdadeira mutação constitucional da norma referente à manifestação do Senado para suspender a lei declarada inconstitucional.

\footnotetext{
${ }^{66}$ STF, RE n. 364.160/MG, Rel. Min. Ellen Gracie, Brasília, 7 fev. 2003.

${ }^{67}$ STF, RE n. 233.332/RJ, Rel. Carlos Velloso, Brasília, 14 mai. 1999.
} 
Para Gilmar Ferreira Mendes, após a Constituição de 1988 e o predomínio do controle abstrato, a lição de Lucio Bittencourt sobre a manifestação do Senado deveria ser revisitada e implementada, alterando o entendimento clássico conferido à norma do art. 52, X da Constituição.

Portanto, é possível resumir a decisão do Ministro Relator da seguinte maneira: por reconhecer mutação constitucional do art. 52, X, em razão das alterações no modelo de controle de constitucionalidade, iniciadas pela Constituição de 88 e aprofundadas pela jurisprudência do STF e por legislações posteriores, passando a predominar o controle abstrato, a decisão do Supremo Tribunal proferida no HC 82.959/SP já seria dotada de eficácia erga omnes, independentemente de resolução do Senado, a qual teria a função apenas de dar publicidade à decisão do Supremo. Dessa maneira, a Reclamação da Defensoria Pública deveria ser julgada procedente, vez que a decisão do Juiz de Direito da Vara de Execuções Penais de Rio Branco decidiu aplicar o art. $2^{\circ}, \S 1^{\circ}$ da Lei n. 8.072/1990, que havia sido declarado inconstitucional no Habeas Corpus mencionado acima.

\subsection{O voto do Ministro Eros Grau}

O Ministro Eros Roberto Grau segue o voto do Ministro Relator, de maneira a reconhecer a ocorrência de mutação constitucional do art. 52, X. Eros Grau entende que a posição do Relator seria a maneira correta para adequar o direito à realidade social.

A tese do Ministro Relator, como esclarece Eros Grau, impõe uma atividade que vai além da produção de uma norma pela interpretação do texto jurídico. O que propõe o Relator, pela mutação constitucional, é a produção de um novo texto.

Dessa maneira, segundo Eros Grau e Gilmar Mendes, haveria a substituição do texto do art. 52, X da Constituição por outro: "ao Senado Federal está atribuída competência privativa para dar publicidade à 
suspensão da execução de lei declarada inconstitucional, no todo ou em parte, por decisão definitiva do Supremo Tribunal Federal”68.

Reconhecendo o dever de analisar os limites do fenômeno da mutação constitucional, defendida em seu voto, o Ministro Eros Grau afirma:

\footnotetext{
"Indague-se, a esta altura, se esse texto, resultante da mutação, mantém-se adequado à tradição [= à coerência] do contexto, reproduzindo-a, de modo a ele se amoldar com exatidão. A resposta é afirmativa. Ademais, não se vê, quando ligado e confrontado aos demais textos no todo que a Constituição é, oposição nenhuma entre ele e qualquer de seus princípios; o novo texto é plenamente adequado ao espaço semântico constitucional"69.
}

Dessa forma, entende o Ministro Eros Roberto Grau que o art. 52, X da Constituição sofreu mutação, passando a figurar com novo texto, sendo o papel do Senado Federal o de conferir publicidade às decisões tomadas pelo Supremo Tribunal Federal em controle de constitucionalidade difuso, as quais já seriam dotadas de efeitos gerais.

Essa mutação constitucional, segundo Eros Grau, seria completamente possível, pois, conforme o voto do Ministro, não estabelece confronto com princípios constitucionais, sendo apenas uma forma do direito se adequar à realidade social.

Por essas razões, o Ministro Eros Grau reconhece a mutação do art. 52, X da Constituição e, portanto, vota no sentido de julgar procedente a reclamação, como havia feito o Ministro Relator.

\subsection{O fenômeno da mutação constitucional}

Visto o posicionamento dos Ministros Gilmar Ferreira Mendes e Eros Roberto Grau, é preciso aprofundar os estudos acerca do fenômeno da mutação constitucional, de maneira a formar juízo quanto à possibilidade de

\footnotetext{
${ }^{68}$ STF, Rcl n. 4.335/AC, Rel. Min. Gilmar Mendes, Brasília, 20 mar. 2014. Voto do Eros Grau.

${ }^{69}$ Ibid.
} 
sua ocorrência em relação à atuação do Senado no controle de constitucionalidade difuso.

O reconhecimento do fenômeno da mutação constitucional remonta à Constituição de 1871 da Alemanha. Neste cenário, Paul Laband notou que as instituições do Reich sofriam algumas mudanças, independentemente de alterações no texto constitucional. Nesse sentido, explica Uadi Lamêgo Bulos:

"Foi aí que Laband, examinando o aludido texto constitucional alemão de 1871, notou importantes modificações neste Diploma Maior, para acompanhar a situação constitucional do império (verfassungszustand), distinguindo a verfassungänderung (reforma constitucional) da verfassungswandel (mutação constitucional)" ${ }^{\text {"70. }}$.

A possibilidade de se reconhecer a mutação constitucional está intimamente ligada à ideia de aplicabilidade da Constituição (não no sentido jurídico, mas no sentido ter conexão com a sociedade), pois, para que isso ocorra, é preciso que a Constituição sofra reformas, de maneira a seguir as alterações pelas quais os valores e ideais das sociedades passam.

A mutação constitucional é espécie do gênero reforma constitucional. Assim, a alteração da Constituição pode ser processada de maneira formal (emendas constitucionais) ou informal (mutações constitucionais). Tanto o processo formal como o informal visam atualizar a Constituição, deixando-a de acordo com a sociedade. Nesse sentido, cumpre destacar lição de Luís Roberto Barroso:

“[...] a modificação da Constituição pode dar-se por via formal e por via informal. A via formal se manifesta por meio da reforma constitucional, procedimento previsto na própria Carta disciplinando o modo pelo qual se deve dar sua alteração. Tal procedimento, como regra geral, será mais complexo que o da edição da legislação ordinária. De tal circunstância resulta a rigidez constitucional. Já a alteração por via informal se dá pela denominada mutação constitucional, mecanismo que permite a transformação do sentido e do alcance de normas da Constituição, sem que se opere, no entanto, qualquer modificação

70 BULOS, Uadi Lamêgo. Da reforma à mutação constitucional. Disponível em < http://www2.senado.leg.br/bdsf/bitstream/handle/id/176380/000506397.pdf? sequence=1>. Acesso em 2 mai. 2017. 
do seu texto. A mutação está associada à plasticidade de que são dotadas inúmeras normas constitucionais" $"$.

Assim, é possível dizer que a reforma constitucional e a mutação constitucional possuem uma atuação complementar, de maneira que se há instrumentos suficientes para haver uma reforma da Constituição, a ocorrência de mutações fica limitada.

Portanto, é possível compreender a mutação constitucional como fenômeno de alteração da Constituição sem que haja um processo formal para essa mudança. Nas palavras de Luís Roberto Barroso:

"[...] é possível dizer que a mutação constitucional consiste em uma alteração do significado de uma determinada norma da Constituição, sem observância do mecanismo constitucionalmente previsto para as emendas e, além disso, sem que tenha havido qualquer modificação de seu texto. Esse novo sentido ou alcance do mandamento constitucional pode decorrer de uma mudança na realidade fática ou de uma nova percepção do Direito, uma releitura do que deve ser considerado ético ou justo. Para que seja legítima, a mutação precisa ter lastro democrático, isto é, deve corresponder a uma demanda social efetiva por parte da coletividade, estando respaldada, portanto, pela soberania popular" ${ }^{\text {72 }}$.

No mesmo sentido do entendimento de Barroso, é possível citar a definição de Uadi Lamêgo Bulos:

"Denomina-se mutação constitucional, o processo informal de mudança da Constituição, por meio do qual são atribuídos novos sentidos, conteúdos até então não ressaltados à letra da Lex Legum, quer através da interpretação, em suas diversas modalidades e métodos, quer por intermédio da construção (construction), bem como dos usos e costumes constitucionais" ${ }^{\text {"73. }}$.

Dessa maneira, é possível entender que a mutação constitucional implica na existência de uma terceira modalidade de poder constituinte, além do poder constituinte originário e o de reforma. Trata-se do poder

\footnotetext{
${ }^{71}$ BARROSO, Luís Roberto. Curso de direito constitucional contemporâneo: os conceitos fundamentais e a construção do novo modelo. $4^{\mathrm{a} e d}$. São Paulo: Saraiva, 2013. p. 146.

${ }^{72}$ Ibid. p. 148 e 149.

73 BULOS, Uadi Lamêgo. Da reforma à mutação constitucional. Disponível em < http://www2.senado.leg.br/bdsf/bitstream/handle/id/176380/000506397.pdf?sequence=1>. Acesso em 2 mai. 2017.
} 
constituinte difuso, que é exercido de maneira informal e ocorre através da interpretação das normas constitucionais e do costume constitucional.

Um exemplo de mutação constitucional reconhecida pelo Supremo diz respeito ao julgamento da ADPF $54^{74}$. Ao julgar essa ação, o STF autorizou a interrupção da gestação de fetos anencefálicos. A Ministra Carmem Lúcia expôs, em seu voto, que "o Código Penal, como qualquer lei, há de se ajustas às mudanças e exigências de uma sociedade em constante evolução e mutação"75.

Assim, a mutação constitucional é um processo informal de alteração da Constituição, pelo qual não há alteração do texto, mas sim do modo como aquele texto é compreendido. Entretanto, isso não deve significar que as mutações se operam sem limites estabelecidos, sob pena de se violar o poder constituinte e se retirar da Constituição o seu elemento estabilizador.

Dessa maneira, Luís Roberto Barroso reconhece dois limites:

“a) as possibilidades semânticas do relato da norma, vale dizer, os sentidos possíveis do texto que está sendo interpretado ou afetado; b) a preservação dos princípios fundamentais que dão identidade àquela específica Constituição. Se o sentido novo que se quer dar não couber no texto, será necessária a convocação do poder constituinte reformador. E se não couber nos princípios fundamentais, será preciso tirar do estado de latência o poder constituinte originário"76.

\subsection{A mutação (in) constitucional do artigo $52, \mathrm{X}$ da Constituição}

Vistos os votos de Gilmar Mendes e Eros Grau e explicado o fenômeno da mutação constitucional, cumpre analisar se, dentro dos limites expostos para a ocorrência do fenômeno, a tese defendida pelos Ministros merece prosperar. Em outras palavras, é possível que as decisões do Supremo em controle difuso sejam dotadas de eficácia erga omnes automaticamente, passando o Senado a ter a função de dar publicidade às decisões do STF, e não mais de suspender a norma inconstitucional?

\footnotetext{
${ }^{74}$ STF, ADPF n. 54/DF. Rel. Min. Marco Aurelio. 30 abr. 2013.

${ }^{75}$ STF, ADPF n. 54/DF. Rel. Min. Marco Aurelio. 30 abr. 2013. Voto da Ministra Carmem Lúcia.

${ }^{76}$ BARROSO, Luís Roberto. Op. cit., p. 150 e 151.
} 
Parte da doutrina contestou a ocorrência de mutação constitucional do art. 52, X. Destaca-se aqui a manifestação dos professores Lenio Luiz Streck, Martonio Mont'Alverne Barreto Lima e Marcelo Andrade Cattoni de Oliveira ${ }^{77}$, que contestam a afirmação feita pelos Ministros Gilmar Mendes e Eros Grau de que o dispositivo fundava-se apenas em razão histórica.

Para os professores a norma do art. 52, X é revestida de um teor democrático, pois a participação do Senado foi a maneira encontrada pelo legislador de a sociedade participar do julgamento da constitucionalidade da norma, ainda que de maneira indireta. A participação da sociedade no controle abstrato é resguardada pela Lei n. 9.868/99 (arts. $9^{\circ}, \S 1^{\circ}$ e $20, \S 1^{\circ}$ ).

Seguindo este raciocínio, passar a entender o Senado como responsável apenas por tornar pública a decisão do Supremo Tribunal representaria a retirada do caráter democrático do controle difuso de constitucionalidade, violando direitos fundamentais, como o devido processo legal, a ampla defesa e o contraditório (art. $5^{\circ}$, LIV e LV, da Constituição).

Apesar do argumento levantado pelos autores acima citados, o art. 52, X da Constituição não parece ter como razão de existência a participação democrática da sociedade no controle difuso de normas, pois, como já anotado neste trabalho, esse instrumento foi concebido pelo constituinte de 1934 como forma de conceder eficácia geral às decisões do Supremo, dotadas apenas de eficácia entre as partes. Ademais, optou-se pela concessão desta competência ao Senado por ele ser, na Constituição de 1934, o responsável pela coordenação entre os Poderes, e não integrante do Poder Legislativo, como era a Câmara dos Deputados.

A existência do instrumento previsto pelo art. 52, X da Constituição parece, de fato, encontrar respaldo apenas na história, não existindo

\footnotetext{
77 STRECK, Lenio Luiz; OLIVEIRA, Marcelo Andrade Cattoni; LIMA, Martonio Mont'Alverne Barreto. A nova perspectiva do Supremo Tribunal Federal sobre o controle difuso: mutação constitucional e limites da legitimidade da jurisdição constitucional. Disponível em: <http://seer.uenp.edu.br/index.php/argumenta/article/view/72>. Acesso em 20 mai. 2017.
} 
nenhuma razão para que não se atribua efeitos erga omnes automaticamente às decisões do Supremo em controle difuso.

Além disso, a atuação do Senado como responsável pela suspensão de uma norma inconstitucional merece ser criticada, pois a Alta Casa do Congresso realiza um juízo político para suspender ou não a norma. A meu ver, essa atuação é danosa para o sistema de controle de constitucionalidade, vez que retira do Supremo Tribunal Federal sua característica de ser o árbitro final na guarda da Constituição. E mais, a não suspensão da norma inconstitucional pelo Senado pode fazer com que cidadãos acabem tendo que percorrer o comprido e vagaroso caminho das instâncias judiciais para terem seus direitos resguardados, mesmo já existindo decisão do órgão máximo do Poder Judiciário neste sentido.

Ademais, a atuação do Senado no controle difuso, como determina o art. 52, X da Constituição, pode colocar esta Casa Legislativa como órgão máximo para decidir a constitucionalidade de uma norma que ela mesma tenha elaborado. Para esclarecer, suponha-se que o Congresso elabore uma determinada lei. Essa lei, em momento posterior à sua publicação, é declarada inconstitucional pelo Supremo em controle difuso de constitucionalidade. Por força do art. 52, X o STF comunica o Senado da inconstitucionalidade da norma. A Alta Casa Legislativa pode, então, realizando juízo político, optar pela não suspensão da norma inconstitucional. Veja-se, nesse caso, o Senado estará concedendo efeitos a uma norma elaborada por ele e declarada inconstitucional pelo Supremo. Ou seja, o Senado atuaria, nesta situação, como juízo da constitucionalidade de seus próprios atos.

Em conclusão, a atuação do Senado pode fazer com que o sistema de controle de constitucionalidade remonte à desastrosa estrutura da Constituição de 1937 (art. 96 $6^{78}$ ), fazendo com que, em razão de um juízo

\footnotetext{
${ }^{78}$ Constituição dos Estados Unidos do Brasil de 1937. “Art. 96 parágrafo único No caso de ser declarada a inconstitucionalidade de uma lei que, a juízo do Presidente da República, seja necessária ao bem estar do povo, à promoção ou defesa de interesse nacional de alta monta, poderá
} 
político, algo que é inconstitucional juridicamente continue produzindo efeitos.

Entretanto, todas essas considerações configuram avaliação qualitativa do instrumento introduzido pela Constituição de 1934. Isso não implica dizer, automaticamente, que o dispositivo em comento tenha sofrido mutação constitucional, como defendem os Ministros Gilmar Mendes e Eros Grau.

A mutação constitucional defendida pelos Ministros, como já exposto, implicaria na transformação do texto do art. 52, X, passando o Senado a figurar como responsável pela publicação da decisão do Supremo, a qual já seria dotada de efeitos gerais.

A mutação constitucional do art. 52, X implicaria em verdadeira transferência de competência, deixando a suspensão da execução da norma declarada inconstitucional de ser feita pelo Senado Federal, e passando a ser feita pelo Supremo Tribunal Federal. Essa alteração vai de encontro ao princípio da separação de Poderes, uma vez que o Supremo, por meio da declaração da mutação constitucional do art. 52, X, usurparia competência do Senado. Por essa razão, o Ministro Sepúlveda Pertence, ao proferir seu voto, entendeu que a mutação constitucional do dispositivo aqui destacado teria "cheiro de golpe de Estado"79.

Esse conflito com o princípio da separação de poderes representa um dos limites à mutação constitucional expostos por Luís Roberto Barroso. Como visto no item anterior deste capítulo, o autor entende ser impossível a mutação constitucional dos "princípios fundamentais que dão identidade àquela específica Constituição"

Além de confrontar com esse limite das mutações constitucionais, a tese defendida pelos Ministros Eros Grau e Gilmar Mendes esbarra na outra limitação do fenômeno, qual seja, os sentidos possíveis de serem atribuídos

o Presidente da República submetê-la novamente ao exame do Parlamento: se este a confirmar por dois terços de voto em cada uma das Câmaras, fica sem efeito a decisão do Tribunal”.

79 STF, Rcl n. 4335/AC, Rel. Min. Gilmar Mendes, Brasília, 20 abr. 2014. Voto do Ministro Sepúlveda Pertence

${ }^{80}$ BARROSO, Luís Roberto. Op. cit., p. 151. 
à norma. Ou seja, a mutação constitucional proposta esbarra na literalidade do dispositivo. Dessa forma, não há como se interpretar o texto do art. 52, $\mathrm{X}$, de maneira a se entender o Senado apenas como responsável por tornar pública a decisão do Supremo sobre a inconstitucionalidade de uma norma, reconhecida em controle incidental.

Portanto, a mutação constitucional do art. 52, X, tal como defendida pelos Ministros Gilmar Mendes e Eros Grau em seus votos no julgamento da Reclamação 4.335/AC configura mutação inconstitucional, por extrapolar os limites do fenômeno.

\title{
4.6. A decisão do Supremo Tribunal Federal na Reclamação 4.335/AC
}

O Ministro Zavascki, em seu voto, que foi o acolhido pela maioria do Tribunal, afasta-se da tese de mutação constitucional apresentada pelo Relator. Isso, entretanto, não significa que ele seguiu a tese dos demais Ministros que se posicionaram contrariamente à tese de Gilmar Mendes. Teori Zavascki reconhece razão a ambas as posições, como é possível perceber pelo seguinte trecho de seu voto:

\begin{abstract}
"No meu entender, a ocorrência, ou não, da mutação do sentido e do alcance do dispositivo constitucional em causa (art. 52, X) não é, por si só, fator determinante do não-conhecimento ou da improcedência da reclamação. Realmente, ainda que se reconheça que a resolução do Senado permanece tendo, como teve desde sua origem, a aptidão para conferir eficácia erga omnes às decisões do STF que, em controle difuso, declaram a inconstitucionalidade de preceitos normativos - tese adotada, com razão, pelo votos divergentes -, isso não significa que tal aptidão expansivas das decisões só ocorra quando e se houver a intervenção do Senado - e, nesse aspecto, têm razão o voto do relator. Por outro lado, ainda que outras decisões do Supremo, além das indicadas no art. 52, X da Carta Constitucional, tenham força expansiva, isso não significa, por si só, que seu cumprimento possa ser exigido diretamente do Tribunal, por via de reclamação" 81 .
\end{abstract}

Teori Zavascki reconhece que algumas decisões são, naturalmente, dotadas de força ultra partes. Como exemplo dessa observação, o Ministro discorre sobre a evolução dos precedentes no Direito brasileiro, constatando

\footnotetext{
${ }^{81}$ STF, Rcl n. 4335/AC, Rel. Min. Gilmar Mendes, Brasília, 20-3-2014. Voto de Teori Zavascki.
} 
que essas decisões possuem eficácia ampliada, para além das partes; além do exemplo dos precedentes, Zavascki reconhece que as decisões proferidas no âmbito de um processo coletivo também são dotadas de eficácia ultra partes, já que os processos dessa natureza transcorrem em regime de substituição processual; e como último exemplo cita o mandado de injunção, uma vez que as decisões proferidas nesses casos têm a função de suprir a omissão legislativa.

Com essas constatações, o Ministro defende que a Resolução do Senado, conforme prevê o art. 52, X da Constituição, consiste em uma das formas possíveis de se ampliar a eficácia das decisões do STF.

Outra forma de decisões do Supremo possuírem eficácia erga omnes e efeito vinculante decorre do controle de constitucionalidade por via de ação, introduzido pela EC n. 16/1965 e ampliado a partir da Constituição de 1988.

A força expansiva das decisões do Supremo foi desenvolvida ainda mais com a Emenda Constitucional n. 45. Por essa emenda, possibilitou-se a edição de Súmulas Vinculantes, as quais possuem força vinculante em relação aos demais órgãos do Poder Judiciário e à administração pública.

Outra mudança trazida pela EC n. 45/2004 relacionada à eficácia geral das decisões do Supremo foi a introdução do requisito de repercussão geral para admissibilidade de recursos extraordinários, sendo determinado, pelo art. 102, § da Constituição Federal, regulamentado pelo art. 1.035, $\S 1^{\circ}$ do CPC (art. 543-A, §1 $\left.{ }^{\circ}, \mathrm{CPC} / 1973\right)$, que a questão deve ultrapassar os direitos subjetivos das partes do processo. Assim, explica Teori:

"Esse segundo requisito [que ultrapassem o interesse subjetivo da causa] evidencia o caráter objetivo de que se reveste a formação do precedente. Justamente com base nessa circunstância, o STF, ao examinar a natureza e o alcance do novo regime, deixou inequivocamente, acentuado o efeito expansivo das decisões dele decorrentes para os demais recursos, já interpostos ou que vierem a sê-lo" $"$. 
Dessa maneira, o Ministro reconhece que diversas decisões do Supremo, além daquelas submetidas ao instituto do art. 52, $\mathrm{X}$ da Constituição, possuem força expansiva. Visto isso, surge o questionamento: como todas essas decisões possuem eficácia ultra partes, um descumprimento delas pode, como ocorre com aquelas submetidas ao instrumento de suspensão pelo Senado, levar ao ajuizamento de uma Reclamação?

O Ministro Teori Zavascki entende que o descumprimento de decisões dotadas de eficácia expansiva importam em ofensa à decisão do Supremo. Entretanto, o Ministro defende uma interpretação restritiva das hipóteses de cabimento de reclamação, para não transformar o STF, fundamentalmente, em órgão fiscal de suas decisões. Dessa maneira, Zavascki afirma:

\footnotetext{
"É que, considerando o vastíssimo elenco de decisões da Corte Suprema com eficácia expansiva, e a tendência de universalização dessa eficácia, a admissão incondicional de reclamação em caso de descumprimento de qualquer delas, transformará o Supremo Tribunal Federal em verdadeira Corte executiva, suprimindo instâncias locais e atraindo competências próprias das instâncias ordinárias. Em outras palavras, não se pode estabelecer sinonímia entre força expansiva e eficácia vinculante erga omnes a ponto de criar uma necessária relação de mútua dependência entre decisão com força expansiva e cabimento de reclamação" 83 .
}

Por essas considerações, o Ministro Teori Zavascki entenderia que Reclamação 4.335/AC não seria cabível no momento em que foi ajuizada. Entretanto, como foi exposto no início deste capítulo, o Supremo editou a Súmula Vinculante n. 26, a qual determina que o juízo de execução deve observar a inconstitucionalidade do art. $2^{\circ}$ da Lei n. 8.072/1990 para efeitos de progressão de regime. Assim, o Ministro votou pela procedência da reclamação.

Com essa argumentação, decidiu o plenário do Supremo afastar a tese de mutação constitucional, mas deu provimento à Reclamação, em razão da edição da Súmula Vinculante n. 26. Por esse entendimento, o 
Tribunal sinalizou que os julgamentos feitos pela Corte devem possuir força de precedente, ou força expansiva, para além das partes do processo, independentemente de atuação do Senado. Entretanto, reconhecer essa característica das decisões do STF, não implica, necessariamente, o cabimento de reclamação contra ato administrativo ou decisão judicial que as contrarie. 


\section{Conclusão}

O presente trabalho teve como objetivo analisar um dos temas mais controversos relativos ao controle de constitucionalidade incidental no Direito brasileiro, qual seja, a atuação do Senado Federal.

O controle de constitucionalidade concreto foi introduzido no Brasil pela Constituição de 1891 e pautava-se no sistema desenvolvido pela Suprema Corte dos Estados Unidos ao julgar o caso Marbury v. Madison, em 1803.

Entretanto, ao introduzir o controle de constitucionalidade difuso aos moldes daquele presente no direito americano, o ordenamento brasileiro não adotou a doutrina do stare decisis, presente nos Estados Unidos, e que torna as decisões da Suprema Corte de observação obrigatória pelos demais órgãos judiciais.

Assim, pelo modelo de controle incidental adotado pela Constituição de 1891, uma decisão sobre a inconstitucionalidade de uma norma tomada pelo Supremo Tribunal produziria efeitos apenas entre as partes envolvidas no processo.

Para conceder eficácia erga omnes à decisão do STF no controle incidental, o constituinte de 1934 elaborou fórmula que previa a participação do Senado Federal, o qual, de acordo com a Constituição de 1934, teria a função de coordenação entre os Poderes.

Dessa maneira, por meio de uma resolução, o Senado poderia suspender a execução da norma declarada inconstitucional pelo Supremo, concedendo eficácia erga omnes àquela decisão que produzia efeitos apenas entre as partes do processo.

O Supremo se posicionou a respeito da manifestação do Senado no controle difuso. Tal fato ocorreu em razão do julgamento do MS 16.512/DF ${ }^{84}$. No julgamento deste Mandado de Segurança, o STF decidiu

\footnotetext{
${ }^{84}$ STF, MS n. 16.512/DF, Rel. Min. Oswaldo Trigueiro, Brasília, 31 ago. 1966.
} 
que a resolução do Senado tinha a função de ampliar os efeitos da decisão da Corte e que a manifestação senatorial era ato discricionário desta Casa Legislativa, inexistindo obrigatoriedade.

Apesar de algumas poucas críticas, como a de Lucio Bittencourt, esse foi o entendimento predominante na jurisprudência e na doutrina. Entretanto, a situação começa a mudar com a ampliação do controle abstrato na Constituição de 1988.

A ampliação do controle abstrato fez com que essa modalidade passasse a predominar em relação ao controle concreto. E mais, o controle concreto sofreu um processo de objetivação, afastando-se do teor subjetivo que detinha, principalmente com a introdução do requisito da repercussão geral pela Emenda Constitucional n. 45/2004.

Em razão dessas modificações pelas quais o sistema brasileiro de controle de constitucionalidade passou, o Supremo Tribunal Federal é chamado a se manifestar novamente acerca do papel do Senado Federal no controle da validade constitucional das normas.

A nova manifestação do Supremo ocorre no julgamento da Reclamação 4.335/AC ${ }^{85}$. Ao julgar essa ação, o Ministro Gilmar Ferreira Mendes defende a ocorrência de mutação constitucional do art. 52, X. A tese do Relator foi seguida pelo Ministro Eros Roberto Grau.

Assim, pela tese de mutação constitucional, o Senado Federal não mais se manifestaria para expandir os efeitos da decisão do Supremo, manifestar-se-ia apenas para dar publicidade à decisão do STF, a qual já seria dotada de eficácia erga omnes.

Apesar das defesas feitas pelos dois ilustres Ministros, a mutação do art. 52, X proposta não seria constitucional, pois ela exorbita a literalidade do texto constitucional, isto é, a redação do dispositivo não comporta a interpretação proposta pelos Ministros. Assim, na realidade, os Ministros propõem um novo texto, revogando aquele presente na Carta Magna. Essa proposta é claramente inconstitucional por não partir do poder constituinte

\footnotetext{
${ }^{85}$ STF, Rcl n. 4335/AC, Rel. Min. Gilmar Mendes, Brasília, 20 mar. 2014.
} 
reformador, que seria o único competente para alterar o texto constitucional, uma vez que não se trata de hipótese de mutação constitucional.

E mais, a proposta de mutação constitucional configuraria usurpação de competência do Senado Federal pelo Supremo, em evidente violação do princípio constitucional da separação dos Poderes. Assim, não é possível admitir que o Supremo Tribunal Federal, por obra exclusivamente sua, passe a exercer competência que, segundo a Constituição, deve ser exercida pelo Senado.

A tese de mutação constitucional do art. 52, X, proposta pelo Ministros Gilmar Mendes e Eros Grau, é incabível. Entretanto, a crítica à existência do instrumento de suspensão pelo Senado de norma inconstitucional é absolutamente pertinente. Nesse sentido, cita-se o Ministro Luís Roberto Barroso:

"[...] não acho boa a solução constitucional de submeter uma decisão do Supremo Tribunal Federal a uma deliberação política do Congresso Nacional. Não acho uma solução feliz. Mas é a que, a meu ver, consta da Constituição. E acho que, diante do impasse que se criou, estabeleceu-se um diálogo institucional entre o Supremo e o Congresso Nacional" 86 .

Posteriormente, conclui o Ministro no voto proferido no julgamento da Reclamação 4.335, o Ministro conclui:

"Portanto, o Supremo acha que esse modelo deve mudar. Porém, como ele está previsto textualmente na Constituição, e nós não somos poder constituinte originário, nem tampouco derivado, eu acho que se pode doutrinariamente concitar o Congresso Nacional a agir. Porém, penso não ser possível interpretar um Texto Constitucional, como nenhum outro texto, contra a sua literalidade, contra as possibilidades semânticas que ele oferece, porque, se assim fosse, nós nos tornaríamos donos da razão e donos da verdade em todo e qualquer caso, e o constituinte seria irrelevante" $" 87$.

\footnotetext{
${ }^{86}$ STF, Rcl n. 4335/AC, Rel. Min. Gilmar Mendes, Brasília, 20 mar. 2014. Voto do Min. Luís Roberto Barroso.

${ }^{87}$ STF, Rcl n. 4335/AC, Rel. Min. Gilmar Mendes, Brasília, 20 mar. 2014. Voto do Min. Luís Roberto Barroso.
} 
Dessa forma, parece inexistir motivos para a subsistência do mecanismo de suspensão de norma inconstitucional pelo Senado. A fórmula prevista pelo art. 52, X parece encontrar respaldo apenas na história. Todavia, a maneira para se alterar esse modelo não pode ser a mutação constitucional declarada pelo Supremo, pois estar-se-ia exorbitando os limites do fenômeno. Há, portanto, um descompasso entre a norma e a realidade. Sobre o tema Cristiano Brandão Vecchi afirma:

\begin{abstract}
"O problema dos limites das mutações se coloca precisamente quando a tensão entre facticidade e normatividade atinge um grau que põe em perigo a noção de supremacia constitucional. Então, a única alternativa possível, neste caso, seria converter a prática convencional (a mutação) em norma através da reforma, ou negar o valor jurídico da mutação, em nome da legalidade existente. Em qualquer das hipóteses, a mutação enquanto tal desapareceria, e a supremacia da Constituição estaria a salvo do perigo de destruição"88.
\end{abstract}

Observa-se, portanto, que a solução ideal para o problema da atuação do Senado no controle de constitucionalidade judicial seria uma emenda constitucional supressiva, retirando do texto constitucional o inciso $\mathrm{X}$ do artigo 52.

${ }^{88}$ VECCHI, Cristiano Brandão. A mutação constitucional: Uma abordagem alemã. Rio de Janeiro. 2005. Tese Mestrado em Direito - Departamento de Direito da PUC-Rio. p. 138/139. 


\section{Bibliografia}

ARISTÓTELES, A Política. Livro III, Cap. XI.

BARROSO, Luís Roberto. Curso de direito constitucional contemporâneo: os conceitos fundamentais e a construção do novo modelo. $4^{\mathrm{a} e d}$. São Paulo: Saraiva, 2013. $511 \mathrm{p}$.

BARROSO, Luís Roberto. O controle de constitucionalidade no direito brasileiro: exposição sistemática da doutrina e análise crítica da jurisprudência. $7^{\mathrm{a} e d}$. São Paulo: Saraiva, 2016. 454 p.

BITTENCOURT, Carlos Alberto Lucio. $O$ controle jurisdicional da constitucionalidade das leis. $2^{\mathrm{a}}$ ed. Rio de Janeiro: Forense, 1968. 164 p.

BONAVIDES, Paulo. Curso de direito constitucional. 30aed.. São Paulo: Malheiros, 2015. 862 p.

BROSSARD, Paulo. O Senado e as leis inconstitucionais. Disponível em < http://www2.senado.leg.br/bdsf/bitstream/handle/id/181304/000393215.pdf ?sequence=3>. Acesso em 20 abr. 2017.

BULOS, Uadi Lamêgo. Da reforma à mutação constitucional. Disponível em

http://www2.senado.leg.br/bdsf/bitstream/handle/id/176380/000506397.pdf ?sequence=1>. Acesso em 2 mai. 2017.

BUZAID, Alfredo. Da ação direta de declaração de inconstitucionalidade no direito brasileiro. São Paulo: Saraiva, 1958. 141 p. 
CAPPELLETTI, Mauro. O controle judicial de constitucionalidade das leis no direito comparado. $2^{\mathrm{a}}$ ed. Porto Alegre: Sergio Fabris, 1992. 142 p.

CAVALCANTI, Themístocles Brandão. Do controle de constitucionalidade. Rio de Janeiro: Forense, 1966. 197 p.

Constituição da República dos Estados Unidos do Brasil (de 16 de julho de 1934). Disponível em http://www.planalto.gov.br/ccivil_03/constituicao/constituicao34.htm>. Acesso em 28 abr. 2017.

Constituição da República dos Estados Unidos do Brasil (de 24 de fevereiro de 1891). Disponível em < http://www.planalto.gov.br/ccivil_03/constituicao/constituicao91.htm>. Acesso em 28 abr. 2017.

Constituição da República Federativa do Brasil de 1967. Disponível em <http://www.planalto.gov.br/ccivil_03/constituicao/constituicao67.htm>. Acesso em 28 abr. 2017.

Constituição da República Federativa do Brasil de 1988. Disponível em <http://www.planalto.gov.br/ccivil_03/constituicao/constituicaocompilado. htm>. Acesso em 29 abr. 2017.

Constituição dos Estados Unidos do Brasil (de 10 de novembro de 1937). Disponível em http://www.planalto.gov.br/ccivil_03/constituicao/constituicao37.htm>. Acesso em 28 abr. 2017.

Constituição Política do Império do Brazil (de 25 de março de 1824). Disponível em 
http://www.planalto.gov.br/ccivil_03/constituicao/constituicao24.htm>. Acesso em 27 abr. 2017.

DALLARI, Dalmo de Abreu. Elementos de teoria geral do Estado. $32^{\mathrm{a}}$ ed. São Paulo: Saraiva, 2013. 306 p.

Emenda Constitucional $n^{o}$ 1, de 17 de outubro de 1969. Disponível em < http://www.planalto.gov.br/ccivil_03/Constituicao/Emendas/Emc_anterior1 988/emc01-69.htm>. Acesso em 28 abr. 2017.

HAMILTON, Alexander. $O$ Federalista $n^{o}$ 78. Disponível em < https://docs.google.com/viewer?a=v\&pid=sites\&srcid=ZGVmYXVsdGRvb WFpbnxkb3dubG9hZGNvbnRldWRvc2RpcmVpdG98Z3g6MTU1MGIzM zA2NDZkNGRmNw>. Acesso em 30 jun. 2017.

LEITE, Fábio Carvalho. Controle de constitucionalidade: aspectos controvertidos. Curitiba: Juruá, 2015. 216 p.

LOCKE, John. Segundo Tratado sobre o Governo. XII, XIII e XIV.

MAQUIAVEL, Nicolau. O Príncipe. XIX.

MELLO, Oswaldo Aranha Bandeira de. Teoria das constituições rígidas. $2^{\mathrm{a}}$ ed.. São Paulo: José Bushatsky, 1980. 248 p.

MELO, Teresa. Mutação constitucional no Brasil e nos Estados Unidos. Disponível em <http://www.agu.gov.br/page/download/index/id/10517916>. Acesso em 19 abr. 2017. p. $303-321$. 
MENDES, Gilmar Ferreira; BRANCO, Paulo Gustavo Gonet. Curso de Direito Constitucional. $8^{\mathrm{a}}$ ed.. São Paulo: Saraiva, 2013. 1424 p.

MONTESQUIEU, O Espírito das Leis. Livro XI, Cap. VI. Disponível em <http://www.escolapresidentevargas.com.br/base/www/escolapresidentevar gas.com.br/media/attachments/331/331/539ef6ac8641be2d6b331d74d2ecf9 6bc0ab67efa1c59_montesquieu.-o-espirito-das-leis.pdf>. Acesso em 3. mar. 2017.

Regimento Interno da Câmara dos Deputados. Disponível em < http://bd.camara.gov.br/bd/handle/bdcamara/18847>. Acesso em 10 abr. 2017.

Regimento Interno do Senado Federal. Disponível em < https://www25.senado.leg.br/documents/12427/45868/RISFCompilado.pdf/ cd5769c8-46c5-4c8a-9af7-99be436b89c4>. Acesso em 10 abr. 2017.

Regimento Interno do Supremo Tribunal Federal. Disponível em < http://www.stf.jus.br/arquivo/cms/legislacaoRegimentoInterno/anexo/RIST F_integral.pdf>. Acesso em 10 mai. 2017.

Revista de Informação Legislativa, ano III, n. 9. Disponível em < http://www2.senado.leg.br/bdsf/handle/id/496744>. Acesso em 10 mai. 2017.

RODRIGUES, Nina Trícia Disconzi; PINÓS, Ondina Maria Paulino. A participação do Senado no controle difuso de constitucionalidade. Disponível em <https://www2.senado.leg.br/bdsf/bitstream/handle/id/496958/000983399.p df? sequence=1>. Acesso em 21 abr. 2017. 
SILVA, José Afonso da. Curso de Direito Constitucional Positivo. $36^{\mathrm{a}}$ ed.. São Paulo: Malheiros, 2012. 928 p.

SILVA, Paulo Napoleão Nogueira da. A evolução do Controle da Constitucionalidade e a competência do Senado Federal. São Paulo: Revista dos Tribunais, 1992. 155 p.

STF, ADI n. 1.919/SP, Rel. Min. Ellen Gracie, Brasília, $1^{\circ}$ ago. 2003.

STF, ADI n. 4.071/DF, Rel. Min. Menezes Direito, Brasília, 22 out. 2009.

STF, ADPF n. 54/DF. Rel. Min. Marco Aurelio. 30 abr. 2013.

STF, AO 499/DF, Rel. Min. Maurício Corrêa, Brasília, $1^{\text {o ago. }} 2003$.

STF, HC n. 82.959/SP, Rel. Min. Marco Aurélio, Brasília, 23 fev. 2006.

STF, Informativo $n . \quad 543 . \quad$ Disponível em < http://www.stf.jus.br/arquivo/informativo/documento/informativo543.htm>. Acesso em 4 abr. 2017.

STF, MS n. 16.512/DF, Rel. Min. Oswaldo Trigueiro, Brasília, 31 ago. 1966.

STF, MS n. 20.505/DF, Rel. Min. Néri da Silveira, Brasília, 8 nov. 1991.

STF, MS n. 23.452/RJ, Rel. Min. Celso de Mello, Brasília, 12 mai. 2000.

STF, Rcl n. 4.335/AC, Rel. Min. Gilmar Mendes, Brasília, 20 mar. 2014.

STF, RE n. 102.553/RJ, Rel. Min. Francisco Rezek, Brasília, 13 fev. 1987. 
STF, RE n. 153.771/MG, Rel. Min. Moreira Alves, Brasília, 5 set. 1997.

STF, RE n. 228.844/SP, Rel. Min. Maurício Corrêa, Brasília, 16 jun. 2009.

STF, RE n. 233.332/RJ, Rel. Carlos Velloso, Brasília, 14 mai. 1999.

STF, RE n. 364.160/MG, Rel. Min. Ellen Gracie, Brasília, 7 fev. 2003.

STF, SE n. 5.206/EP, Rel. Min. Sepúlveda Pertence, Brasília, 30 abr. 2004.

STJ, RMS n. 11.824/SP, Rel. Min. Francisco Peçanha Martins, Brasília, 27 mai. 2002.

STRECK, Lenio Luiz; OLIVEIRA, Marcelo Andrade Cattoni; LIMA, Martonio Mont'Alverne Barreto. A nova perspectiva do Supremo Tribunal Federal sobre o controle difuso: mutação constitucional e limites da legitimidade da jurisdição constitucional. Disponível em: $<$ http://seer.uenp.edu.br/index.php/argumenta/article/view/72>. Acesso em 20 mai. 2017.

U.S. Supreme Court, William Marbury v. James Madison, Feb 1803. Disponível em $<$ https://www.law.cornell.edu/supremecourt/text/5/137\#writingUSSC_CR_0005_0137_ZS>. Acesso em 23 abr. 2017.

VECCHI, Cristiano Brandão. A mutação constitucional: Uma abordagem alemã. Rio de Janeiro. 2005. Tese Mestrado em Direito - Departamento de Direito da PUC-Rio. 148 p. 
ZAVASCKI, Teori. Eficácia das sentenças na jurisdição constitucional. Disponível em https://www.lume.ufrgs.br/bitstream/handle/10183/2521/000275909.pdf?se quence $=1>$. Acesso em 2 maio 2017. 